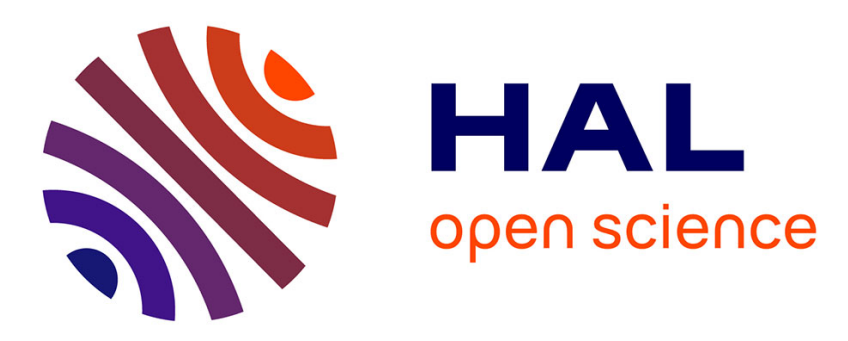

\title{
Semi-distributed lumped model of a karst system under active management
}

Bernard Ladouche, Jean-Christophe Maréchal, Nathalie Dörfliger

\section{To cite this version:}

Bernard Ladouche, Jean-Christophe Maréchal, Nathalie Dörfliger. Semi-distributed lumped model of a karst system under active management. Journal of Hydrology, 2014, 509, pp.215-230. 10.1016/j.jhydrol.2013.11.017 . hal-00905925

\section{HAL Id: hal-00905925 \\ https://hal-brgm.archives-ouvertes.fr/hal-00905925}

Submitted on 18 Nov 2013

HAL is a multi-disciplinary open access archive for the deposit and dissemination of scientific research documents, whether they are published or not. The documents may come from teaching and research institutions in France or abroad, or from public or private research centers.
L'archive ouverte pluridisciplinaire HAL, est destinée au dépôt et à la diffusion de documents scientifiques de niveau recherche, publiés ou non, émanant des établissements d'enseignement et de recherche français ou étrangers, des laboratoires publics ou privés. 


\title{
1 Semi-distributed lumped model of a karst system under active
}

\section{2 management}

\author{
Bernard LADOUCHE ${ }^{1 *}$, Jean-Christophe MARECHAL ${ }^{1}$ and Nathalie DORFLIGER ${ }^{2}$
}

1. BRGM, Water Environment \& Ecotechnologies Division, 1039 rue de Pinville, F-34000, France

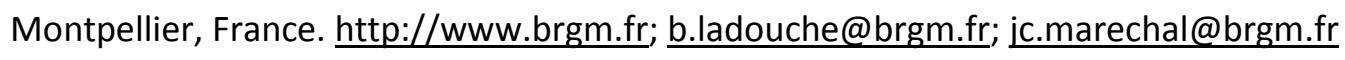

2. BRGM, Water Environment \& Ecotechnologies Division, 3 avenue Claude Guillemin, BP 36009 F-45060 Orléans cedex 2, France. n.dorfliger@brgm.fr

*corresponding author: Tel.: 334671576 80; Fax: 33467157975

\section{Abstract}

In this paper inverse modeling is used to characterize the regime of a karst aquifer subjected to extensive pumping in a conduit located upstream of its main outlet. The systemic approach uses a transfer model that is based on computing the convolution integral of up to several signals, e.g., efficient rainfall, pumping, to simulate flow rates and groundwater levels in both the karst conduit and the carbonate matrix at the aquifer outlet and in several parts of the catchment area. The model is a semi-distributed lumped model which simulates the hydrological response of a heterogeneous karst aquifer made up of different hydrologic compartments, and is applied to the Lez karst system, France. Groundwater is abstracted near the system's major outlet at a higher rate than the lowwater spring discharge, thereby mobilizing stored groundwater during low-water periods ('active management').

The model's results are very satisfactory, especially for the karst system outlet, where the water levels are particularly well reproduced. The model can also simulate the natural, i.e., non-pumping, 
22 state of the karst system and thereby estimate the impact of active management on the water

23 resource.

\section{Highlights}

25 Characterization of karst functioning using a lumped semi-distributed approach

26 Interpretation of a very long times series of groundwater levels in a karst system

27 New insights on the mobilization of stored reserves by pumping within a karst system

29 Keywords

$30 \quad$ Impulse response

31 Groundwater flow modeling

32 Groundwater level fluctuations

$33 \quad$ Pumping

\section{$34 \quad$ Introduction}

35 Numerical models for karst aquifers usually fall within two main categories (Goldscheider and Drew 2007): lumped-parameter or reservoir models (Dreiss 1983; Pinault et al., 2001a, b, 2004) and

37 distributed physical models (Birk et al., 2003; Liedl et al., 2003). Owing to the high degree of heterogeneity of karst aquifers, distributed models (Birk et al., 2000; Teutsch and Sauter, 1998) can

39 be relatively difficult to implement and calibrate because of difficulties in obtaining the necessary

40 input data. These difficulties have limited the use of such models in karst hydrogeology. Dual-

41 porosity models with implementation of discrete pipe networks within a limestone matrix (Cornaton 
and Perrochet, 2002) represent a promising approach for testing hypotheses on the conceptual representation of water interactions between the matrix and pipe networks. However, because the available data on karst conduit geometry are generally very limited, this modeling approach is difficult to implement. The lumped-parameter model is simpler and considers the karst as a whole; it uses the relationship between rainfall and discharge (bivariate analysis) to characterize the karst flow regime, and can potentially be used for a karst hydrosystem in which these data are available (DenicJukic and Jukic 2003; Dorfliger et al., 2009; Padilla and Pulido-Bosch 2008; Jukic and Denic-Jukic 2009; Martínez-Santos and Andreu 2010, Moussu et al., 2011, Long and Mahler, 2013). However, some karst aquifers are characterized by geographical or hydrogeological subsystems that can be considered as homogeneous units at the scale of interest which potentially are hydraulically connected to each other at the scale of the karst catchment area. In such cases, a lumped parameter model applied to the overall catchment cannot take this hydrodynamic heterogeneity into account. One option, if the necessary data are available, is to consider a lumped parameter modeling approach for each subsystem and then to aggregate the results in order to represent the overall flow regime of the karst aquifer at its outlet. This is an intermediate approach between the lumped parameter model and the distributed physical model, and here is termed a semi-distributed lumped parameter model.

Karst aquifers can form major groundwater reservoirs (Bakalowicz 2005) and are locally pumped to meet growing drinking-water requirements due, in particular, to population growth. 'Active management' through pumping from the main karst conduit in the vicinity of its outlet enables optimal exploitation of a karst groundwater by avoiding the negative effects of large low-water discharge variations at the springs. Active management can thus be defined as pumping at a flow rate greater than the spring's low-water discharge rate so as to mobilize the aquifer's stored reserves (Avias 1995). These reserves are then replenished during the following rainy season, resulting in less intense floods at the start of the season (Fleury et al. 2008). In such cases the karst system is 
characterized by two distinct types of flow regime: (i) a high-water flow regime when the natural outlet discharge is greater than the pumping rate and the system functions naturally; and (ii) a lowwater flow regime when the natural outlet discharge is lower than the pumping rate, and the pumped flow rate is the sum of the natural outlet discharge plus the mobilized karst storage flow desaturating the conduits and the matrix (Maréchal et al., 2008). Generally, when a karst system has been exploited over a long period, no observations of the system's natural flow regime are available and it is therefore difficult to reconstruct the system's 'natural' rainfall-discharge relationship: this is a similar to attempting to determine hydrological processes in ungauged basins (Sivapalan 2003).

The Lez spring karst system, in southern France, has been an ideal site since the 1970s for studying and modeling a flow regime. Most of the numerical models developed for studying the aquifer's hydrodynamics with a view to groundwater exploitation are based on the laws for draining several reservoirs (Guilbot 1975; Thiery et al., 1983, Fleury et al., 2008). These models are thus unable to describe the functioning of the various hydrogeological units of the hydrosystem, and especially that of the western compartment of the Matelles Fault (Massili 2011; Massili et al, 2011). The main aim of our work here was to develop a lumped parameter modeling approach suitable for (i) a karst system whose overall flow regime results from the juxtaposition of identified subsystems, and (ii) a system that was under 'active management' for a long period of time and for which the natural flow regime, in particular at the outlet, is unknown. The final objective of this work was to develop a modeling approach that is able to predict the water levels and spring discharge so that the impact of global change scenarios on the Lez karst system could be assessed.

\section{Study area}

The Lez karst system forms part of the North Montpellieran Garrigue hydrogeological unit delimited by the Hérault river (to the west) and the Vidourle river (to the north and east, Figure 1). The Lez karst aquifer, between 650 and $800 \mathrm{~m}$ thick, lies within the Upper Jurassic layers on both sides of the 
Matelles-Corconne Fault (here termed the 'Matelles Fault'). The aquifer is unconfined in the western compartment of this fault and locally confined in the eastern compartment (Figure 2a). The base and top of the Lez karst aquifer in the eastern compartment are respectively Callovian-Oxfordian marls (Middle Jurassic) and a thick succession of Lower Valanginian (Lower Cretaceous) marls and marly limestone; the aquifer itself straddles in the Upper Jurassic and the Berriasian (Lower Cretaceous). The karstification of the main conduit below its top wall in the eastern compartment was confirmed as $-10 \mathrm{~m}$ (a.s.l.) by diving, and down to $-48 \mathrm{~m}$ (a.s.l.) by drilling (Figure 3 ). The geometry of the conduit is known only between the spring and a few boreholes located 400 meters away: this lack of knowledge at the watershed scale prohibits the application of any distributed modeling approach. A southward structuring of the aquifer, with the development of karstification at depth and an underground drainage in the direction of the Mediterranean, is probable and almost certainly related to the Messinian salinity crisis (Clauzon et al., 2005; Avias 1992). However, the compressive tectonics of the Eocene Pyrenean-Provençal phase, in addition to filling the paleo-outlet with impermeable Miocene and Pliocene sediments from the Messinian canyons, gave this large karst aquifer a 'confined karst' character with the presence of upstream overflow springs, such as the Lez spring and the intermittent Lirou spring.

The Lez spring with its overflow at $65 \mathrm{~m}$ (a.s.I.) is the main outlet from the karst system. The area of the hydrogeological catchment is estimated to be $380 \mathrm{~km}^{2}$, based on the geology, identification of the impervious structural limits, dye tracings, and groundwater level dynamics in the network of observation boreholes during the drawdown in the spring's conduit (Thiery et al., 1983, Figure 1). Several recharge zones can be identified within this basin according to the nature of the exposed geological formation: (i) the Jurassic limestone outcrop (between 80 and $100 \mathrm{~km}^{2}$ ) is the main area of recharge from effective rainfall (Figure 1); (ii) the Cretaceous marly-limestone formations $\left(120 \mathrm{~km}^{2}\right)$, which are much less permeable than the Jurassic, provide leakage to the underlying Jurassic and contain identified loss zones with direct recharge to the underlying Jurassic aquifer from surface 
streams (swallow holes) and in particular along tectonic faults; (iii) the Tertiary formations $\left(160 \mathrm{~km}^{2}\right)$, which are generally impervious and which contribute insignificantly to the karst aquifer recharge.

The Lez spring has been supplying the city of Montpellier since 1854. Prior to 1968 , the resource was exploited through spring overflow collection, which ranged between 25 and 600 l/s (Paloc 1979). From 1968 to 1982, abstraction was carried out by pumping in the panhole at a rate of some $800 \mathrm{l} / \mathrm{s}$.

This period was the prelude to 'active management' of the Lez karst system, with pumping rates in the summer periods being greater than the natural discharge without any pumping. By the end of the 1970s increased demand for drinking-water supply had motivated the managers to extract the resource at a rate higher than $800 \mathrm{l} / \mathrm{s}$. For this reason, in 1982 deep wells were drilled into the main karst conduit upstream of the spring in order to obtain a maximum yield of $2000 \mathrm{l} / \mathrm{s}$ (Avias 1995). The current pumped rates at the low-water stage (between 1200 and $1700 \mathrm{l} / \mathrm{s}$ ) are greater than those pumped at high water $(900 \mathrm{l} / \mathrm{s})$. The maximum pumping rate is now fixed at $1700 \mathrm{l} / \mathrm{s}$ so that the minimum water level (Figure 4) is no lower than 35 m.a.s.l., i.e., $30 \mathrm{~m}$ below the elevation of the spring's outlet. A reserve flow of $160 \mathrm{l} / \mathrm{s}$ returns to the Lez River downstream of the spring when the spring is not overflowing.

The karst system's natural discharge (Qn) is unknown, because the Lez spring has been tapped since 1854 (Paloc 1979). However, the pumping rate (Qp) has been measured since 1974 and the spring's residual overflow discharges (Qr) were reliably measured between 1987 and 2007. The natural highwater flows over this period can be estimated by the equation $Q n=Q r+Q p$ (Figure 3a) -the natural discharges (Qn) estimated from these measurements are shown in Figure 5a.

At low-water stage (Figure 3b), the pumping rate (Qp) is between 1200 and $1700 \mathrm{l} / \mathrm{s}$, which is higher than the natural discharge (Qn) would have been in the absence of pumping. The pumping caused the spring to dry up ( $Q r=0)$. Accordingly, the pumped discharge $(Q p)$ during the low-water period is interpreted as the sum of the flow that would have occurred naturally in the absence of pumping 
140 (Qn) and the storage flow (Qs) mobilized by the pumping: $Q p=Q n+Q s$. The yield obtained from the 141 karst storage (Qs) is interpreted as coming from depletion of the karst conduits and mobilization of matrix water from the carbonates in which the karst drainage network has been developed (Maréchal et al, 2008). Pumping thus mobilizes the karst system's water reserves that are barely or not at all accessible under the karst's natural flow regime. This is reflected in a lowering of the piezometric head ( $\mathrm{H} 4)$ in the karst conduit ( $35 \mathrm{~m}<\mathrm{h} 4<65 \mathrm{~m}$ a.s.l.; Figure $3 \mathrm{~b})$.

The Suquet borehole (Figure 2a) intersects the karst conduit connected to the Lirou spring, which is the main outlet from the Western compartment of the Lez karst system (Paloc 1987): it thus enables a description of the overall hydrodynamics of this part of the system. During high-water periods ( $\mathrm{H} 2>65$ m.a.s.l.) the groundwater-level response to effective rainfall recharge is very similar to that recorded at the Claret observation borehole. This is located in a conduit in the immediate vicinity of the Matelles Fault (Fig. 1), which is one of the main drainage axes of the karst system (Lacas 1976; Drogue and Grillot 1976; Bérard 1983; Karam 1989). During low-water periods (h2 <65 m.a.s.l.), groundwater-level monitoring reveals the existence of a 'groundwater disconnection' between the two aquifer compartments located on either side of the Matelles Fault (Figure 4). The groundwater level in the western compartment (Suquet borehole) is no longer influenced by drawdowns caused by pumping when the groundwater head of the karst conduit at Claret is 53.5 m.a.s.l. or 52 m.a.s.l. at the Lez observation borehole (Figure 4). The measured groundwater levels at the Suquet observation borehole can be explained if one considers that a 'cascade'-type disconnection exists in the conduit.

159 This does not preclude a water flow from the western compartment continuing to supply the Jurassic located below the Cretaceous cover in the eastern compartment, but the two hydraulic heads measured on either side of the Matelles Fault are independent. The Suquet observation borehole is representative of the karst system draining the western compartment of the Matelles Fault. be influenced by the pumping (Conroux 2007); but indicates a different hydrodynamic response from 
the conduit (Lez, Claret, Figure 4), which exhibits a much more inertial groundwater behavior (Conroux, 2007), one that we assume is representative of the matrix storage beneath the Cretaceous cover to the east of the Matelles Fault (Figure 2a).

\section{Semi-distributed lumped model}

The semi-distributed lumped modeling approach developed for the present study is based on the state of knowledge concerning the Lez karst system. The architecture of the hydrological model is shown in Figure $2 \mathrm{~b}$. Four sub-models (or modules) was used to reproduce the hydrodynamic flow regime of a complex karst aquifer, composed of two compartments (the western and eastern parts of the Matelles fault), and subjected to an 'active management' through pumping at the Lez spring (Figure 2a). The first three modules simulate (i) the natural discharge of the Lez spring (Qn), and the water levels in (ii) the karst conduit of the western compartment at the Suquet observation borehole $(\Delta \mathrm{H} 2)$ and (iii) the matrix of the eastern compartment at the Laudou observation borehole $(\Delta \mathrm{H} 3)$. The fourth module calculates the groundwater level of the main karst conduit at the Lez spring $(\Delta \mathrm{H} 4)$ from the contributions (outputs) of the three intermediate transfer modules.

The hydrogeologic modeling was performed using transfer methods implemented with TEMPO software (Pinault, 2001). The calculation of the impulse responses of the transfer modules is achieved by inverse modeling with stress positivity. The term inverse modeling is here restricted to the parameter identification of convolution kernels used to simulate the output from the input. Computation of the impulse response uses regularization methods inspired by Tikonov and Arsenime (1976), Tikonov and Goncharsky (1987), and Dietrich and Chapman (1993), as described by Pinault et al. (2001a). The calculation of impulse responses under stress allows to satisfying the principle of conservation of the water mass. The impulse responses can be parametric or non-parametric. In the case of a non-parametric impulse response, the system is termed ill-posed from a numerical point of view because it has an infinite number of solutions. As mentioned by Doherty and Skahill (2006), the so-called "Tikhov regularization", in which the parameter estimation process is formulated as a 
constrained minimization problem, enables an efficient and stable solution to the inverse problem to be obtained. The mathematical and numerical bases used in Tempo software for the calculation of impulse responses are presented in Pinault et al. (2001a). The search for a solution by the regularization technique seeks to reduce the number of degrees of freedom of the optimization problem by minimizing the norm of the transport equation (i.e eq. 7, eq. 9, eq. 11 and eq. 13 in this study). Among all possible solutions, the calculation of minimizing the norm of the solution aims to select the one with the smallest norm in order to smooth the non-parametric impulse response. As indicated by Pinault et al. (2001a), the regularization parameter (w) is optimized by using the method of the curve L. This technique takes its name from the shape of the curve obtained when the $\mathrm{x}$-axis represents the norm of the solution and the $y$-axis the difference between the model and the observations. The regularization parameter $(w)$ is selected as close as possible to the angular points of the curve L. This choice is a compromise between (1) choosing a very smooth solution which produces a poor fit, and (2) choosing a very irregular solution producing an excellent fit between the model and the observations. The regularization parameter $(w)$ is the absolute value of the derivative of the curve L. The second parameter of the non-parametric impulse response is the maximum length over which the computation is performed.

The modeling approach using Tempo software enables a characterization of the flow regime of complex hydrosystems such as those found in karst systems (Pinault et al., 2001b, 2004; Dörfliger et al., 2009) as well as in more homogeneous porous media (Pinault et al. 2005; Pinault and Schomburgk 2006; Pinault and Allier 2007).

\section{Effective rainfall}

The modules use the same daily input data to compute the effective rainfall, with the possibility of using several rain gauges ( $p$ being the number of rain gauges) for the rainfall data:

$$
R_{\Sigma}=\sum_{k=1, p} \delta_{k} R_{k} \quad \delta_{k} \geq 0 k=1, \ldots, p \quad \sum_{k=1, p} \delta_{k}=1
$$


The sum $R_{\Sigma}$ of a series of rainfall data is defined so as to optimize the contribution of each rain gauge to the transfer model of the spring's discharge (Module 1). The principle, given by Pinault et al. (2005) consists of computing the weighting factors $(\delta k)$ of the rain gauges so that they maximize the cross-correlation between rainfall and system output.

The amount of effective rainfall $R_{\text {eff }}(t)$ inducing a flow variation for a time $\mathrm{t}$ is calculated by:

$$
R_{\text {eff }}(t)=R_{\Sigma}(t)-\Omega(t) \text { if } R_{\Sigma}(t) \geq \Omega(t) \text { otherwise } R_{\text {eff }}(t)=0
$$

The effective rainfall $\left(R_{\text {eff }}\right)$ is calculated by computing the threshold function Omega:

$$
\Omega(t)=G r * R_{\Sigma}(t)+G T a * T a(t)+C
$$

where * is the discrete convolution product, $t$ the time, $C$ a constant, and $G r$ and $G T a$ the impulse responses such that $G T a>0$ and $G r<0$. These two impulse responses ( $G r$ and $G T a$ ) are represented by trapezia (Figure 5c). Details of the impulse response parameter calculation are presented in Pinault et al. (2001a).

The threshold $\Omega(t)$ is used to express the deficit of the effective reserve in the ground. Rain decreases the $\boldsymbol{\Omega}(t)$ threshold, following the reservoir's recharge, while air temperature $(T a)$ increases it. The convolution of rain with the negative part of the impulse response (Figure 5c) gives the contribution of rain threshold $\Omega(\mathrm{t})$. The threshold $\Omega(t)$ (Eq. 2) can be computed using the air temperature (Ta) because the input and output variables are reduced (divided by their mean). Consequently, only the variations are involved and it is these that determine the model's accuracy (Pinault 2001). The airtemperature records used in the calculation (Eq. 2) are from the St-Martin de Londres meteorological gauging station (Figure 1).

The effective rainfall $R_{\text {eff }}(t)$ is divided into two components: $R_{\text {eff }}(t)=R_{s}(t)+R_{f}(t)$, where $R_{s}(t)$ and $R_{f}(t)$ are the components of effective rainfall that respectively induce the slow and fast responses of the 
system. The fast component is assumed to be representative of the fast infiltration which occurs only after high-rainfall events. The component $R_{f}(t)$ is expressed according to $R_{e f f}(t)$ by the Alpha function $[\alpha(t)]$ :

$$
R_{f}(t)=\alpha(t) \times R_{e f f}(t)
$$

where $\alpha(t)$ is the proportion of effective recharge (its values lie between 0 and 1 ). The Alpha function enables consideration of the non-linear switching behavior of karst systems such as 'Flush flow' which depends on the effective rainfall over the preceding days. The Alpha function is related to the effective recharge by the convolution product:

$$
\alpha(t)=\Gamma_{\alpha, \operatorname{Re} f f} * R_{e f f}(t)
$$

where $*$ is the discrete convolution product, $t$ the time, and $\Gamma_{\alpha, \operatorname{Re} f f}$ the impulse response of $\alpha(t)$ to effective rainfall $R_{\text {eff }}(t)$. The impulse responses are represented by trapezia (Figure $5 \mathrm{~d}$ ).

\section{Module 1: Transfer model for the rainfall -Lez spring natural discharge relationship}

The first module (Figure 2b) computes the natural discharge of the Lez spring (Qn) which would flow naturally in the absence of pumping and the mobilized storage flow (Qs). Inverse modeling of the natural flow consists of calculating both the slow $(\tau s)$ and fast $(\tau f)$ impulse responses associated with the different types of flow that occur within the karst system. The fast transfer $(\tau f)$ may be associated with 'flush flow'. This can occur when hydraulic continuity is established between the unsaturated and saturated zones of the karst through a temporary connection between groundwater in the epikarst and the saturated zone, via fractures and/or subvertical conduits (Pinault et al., 2001b). 'Flush flow' has been demonstrated in the Fontanilles and Cent-Fonts karst systems to the north of Montpellier (Aquilina et al., 2005, 2006) during periods of major recharge. The impulse response of the fast flow $(\tau f)$ can also describe the contribution of losses from temporary streams 
located in the catchment area of the Lez spring. In the model, the fast transfer of the recharge $(\tau f)$ is obtained by the convolution product of a Gaussian function with a decreasing exponential:

$$
\left\{\begin{array}{c}
\tau f\left(t_{i}\right)=A \cdot \exp \left(-\ln (2)\left(\frac{\left(t_{i}-T\right)}{D}\right)^{2}\right) * \exp \left(\frac{-t_{i} \ln (2)}{L}\right) \text { if } 0 \leq t_{i} \leq \tau \\
\tau\left(t_{i}\right)=0 \text { if } t_{i}>\tau
\end{array}\right.
$$

From a physical viewpoint, the model reflects the recharge of a reservoir (Gaussian function) followed by its rapid depletion represented by the decreasing exponential law. The succession of these two phenomena is described by the convolution product $\left({ }^{*}\right)$. The parameter $T$ expresses the delay of the recharge process with respect to the rainfall, while the parameter $D$ reflects the duration of the event. $A$ is the normalization constant.

The slow transfer $(\tau S)$ brings into play the various infiltration and depletion processes inducing a more-or-less significant delay between the rainfall and the observed discharge. The depletion of the saturated zone is also described by this slow transfer. In the approach we adopted, the slow transfer of the recharge $(\tau S)$ is described by a parametric model (Denic-Jukic and Juckic 2003) that convolves an analytical function consisting of two reservoirs in parallel, and the depletion of the saturated zone is described by a decreasing exponential function. The choice of this type of parametric model can be justified by the existence of the two karst compartments located on either side of the Matelles Fault. The expression for the two unequal parallel linear reservoirs with recession coefficients $k 1$ and $k 2$ is:

$$
\tau S=\frac{\theta}{k 1} e^{-t / k 1}+\frac{1-\theta}{k 2} e^{-t / k 2}
$$

where the parameter $\theta$ represents the flow ratio between the two reservoirs. The impulse response is presented on Figure 5e.

The discharge $Q n(t)$ is computed by the following equation (Eq. 7):

$$
Q n(t)=A\left(\tau f^{*} R f+\tau s^{*} R s\right)
$$


Where * represents the discrete convolution product, $t$ the time, $Q n(t)$ the flow of the hydrosystem,

$A$ the recharge area of the catchment basin (where recharge occurs), $\tau f$ and $\tau S$ the normalized impulse responses (the area being the unity), and $R f$ and $R s$ the components of the effective rainfall $(R e f f=R f+R s)$ inducing the fast and slow transfers respectively. The inverse modeling process calculates the normalized impulse responses $\tau s$ and $\tau f$, the effective rainfall $\left[R_{\text {eff }}(t)\right]$, and the part of effective rainfall $[\alpha(t)]$ that is involved in quick flow.

The karst storage flow (Qs) mobilized by the pumping is then calculated as follows:

$$
\begin{aligned}
& \text { if } Q p \geq Q n \text { then } Q s=Q p-Q n \text { and } Q r=0 \\
& \text { if } Q p<Q n \text { then } Q s=0 \text { and } Q r=Q n-Q p
\end{aligned}
$$

where $Q s$ represents the karst storage flow, $Q p$ the pumping rate, and $Q n$ the natural flow in the absence of pumping. The karst storage flow (Qs) is negative (by convention) and is assumed to be zero when there is overflow at the outlet (high water). The karst storage volume $V s$ calculated from Qs is different from the dynamic volume $V d$ which would have flowed in the absence of pumping, the latter generally being assessed from the analysis of recession curves (Mangin 1975).

\section{Module 2: Transfer model for the rainfall - Lirou spring discharge relationship (Western compartment)}

The second or Suquet module (Figure 2b) simulates the hydraulic head of the conduit $\left(\Delta H_{2}\right)$ in the Jurassic compartment west of the Matelles Fault (Suquet borehole; Figure 1 and Figure 2a) near the Lirou overflow spring. The relationship between the recharge (input) and the piezometry (output) is based on computing a non-parametric impulse response

$$
H 2(t)=\frac{1}{\eta 2} \Gamma_{2} * R_{e f f}+\varepsilon
$$

where $\Gamma_{2}$ is the normalized impulse response (area equal to 1 ) of the effective rainfall recharge and $\eta 2=W s \times \operatorname{Max}\left(\tau_{2}\right)$, a constant linked to the porosity $(W s)$ through determination of the base 
piezometric level $\mathrm{H}_{0}$ (Pinault 2001) and the maximum value of the normalized impulse response $\left(\tau_{2}\right)$; $\varepsilon$ represents the erratic contribution that is not described and explained by the model. The computation of the impulse responses is performed under positivity constraint and while satisfying the principle of conservation of the mass of water, the groundwater level being expressed relative to a reference level HO. This reference level is the groundwater level in the absence of external solicitation (effective recharge, pumping). The inverse modeling is set up to calculate the normalized impulse response $\left[\Gamma_{2}\right]$ (Figure $6 c$ ), the threshold $\Omega(t)$ (Figure $6 b$ ), and the effective rainfall. Parameters are obtained through inversion by minimizing the quadratic form:

$\sum_{i=1}^{N}\left(H 2_{o b s}\left(t_{i}\right)-H 2_{\text {mod }}\left(t_{i}\right)^{2}\right.$

Eq. 10

The slow component can reproduce the hydrological response of the western compartment (Figure 6c). The fast component is not necessary for this module.

\section{Module 3: Transfer model for the matrix storage (Eastern compartment)}

The third or Laudou module is used to characterize the functioning of the Jurassic karst beneath the Cretaceous cover (Figure $\mathbf{2 b}$ ) in the eastern compartment of the Matelles Fault. This transfer model takes into account the recharge by effective rainfall as well as the effect of the karst storage flow (Qs) mobilized by pumping.

The piezometric evolution is described by the following convolution equation:

$$
H 3(t)=\frac{1}{\eta 3} \cdot \Gamma_{3} * R_{e f f}+\lambda_{3 s} \cdot \Gamma_{3 s} * Q_{S}+\varepsilon
$$

where $\Gamma_{3}$ and $\Gamma_{3 s}$ are the normalized non-parametric impulse responses (areas equal to 1 ), $\Gamma_{3}$ is the normalized impulse response of the recharge from effective rainfall, and $\Gamma_{3 s}$ is the normalized impulse response of the mobilized karst storage flow; $\varepsilon$ represents the erratic contribution that is not described and explained by the model. The parameters $\frac{1}{\eta 3}$ and $\lambda_{3 s}$ are positive coefficients for expressing the conservation of the water mass: 
326 The term $\frac{1}{\eta 3} \cdot \overline{R_{e f f}}$ is used to describe the relative contribution of the recharge and $\lambda_{3 s} \cdot \overline{Q_{S}}$ describes

327 the relative decrease in piezometry resulting from the karst storage flow $\left(Q_{s}\right)$ mobilized by pumping

328 in the conduit of the Lez spring.

The inverse model of fissured matrix storage in the Jurassic karst beneath the Cretaceous cover is represented in Figure 7 . The inverse modeling calculates the threshold $\Omega(t)$ (Figure $7 \mathrm{~b}$ ) and the effective rainfall, the normalized impulse response of the recharge $\left(\Gamma_{3}\right)$, and the normalized impulse response of the karst storage flow mobilized by pumping $\left(\Gamma_{3 S}\right)$. The impulse responses of the two contributions $\Gamma_{3}$ and $\Gamma_{3 s}$ are shown in Figure $7 \mathrm{~b}$. The computation of the impulse responses is performed under positivity constraint, the groundwater level being expressed relative to a reference level HO. The fast component is not necessary for this module.

Module 4: Transfer model for the main conduit to the Lez springhead

Module 4 (Figure $\mathbf{2 b}$ ) enables a simulation of the water level of the Lez karst conduit in the immediate vicinity of the spring (borehole located $400 \mathrm{~m}$ upstream of the Lez spring) and thus to characterize the global hydrodynamics of the system at the outlet. Module 4 is a system convolved in sequence since the outputs of Modules 2 and $3[\mathrm{H} 2(\mathrm{t})$ and $\mathrm{H} 3(\mathrm{t})]$ are the inputs to the convolution kernel of the simulation model for the water level [H4 (t)].

The piezometry is calculated by the following convolution equation:

$$
H 4(t)=\lambda_{a} \cdot \Gamma_{a} * R_{e f f}+\lambda_{b} \cdot \Gamma_{b} * Q_{S}+\lambda_{c} \cdot \Gamma_{c} * H_{2}+\lambda_{d} \cdot \Gamma_{d} * H_{3}+\varepsilon
$$


component from the Jurassic aquifer lying to the west of the Matelles Fault (computed by the Suquet module); $\Gamma_{d}$ is the normalized response of the supply component from the matrix (computed by the Laudou module); and $\varepsilon$ represents the erratic contribution that is not described or explained by the model.

$\lambda_{a}, \lambda_{b}, \lambda_{c}$ and $\lambda_{d}$ are positive coefficients for expressing the conservation of the water mass:

$$
\lambda_{a} \cdot \frac{\overline{R_{e f f}}}{\Delta H_{4}}+\lambda_{b} \cdot \frac{\overline{Q_{S}}}{\Delta H^{4}}+\lambda_{c} \cdot \frac{\overline{\Delta H_{2}}}{\Delta H_{4}}+\lambda_{d} \cdot \frac{\overline{\Delta H_{3}}}{\Delta H_{4}}=1
$$

The term $\lambda_{b} \cdot \overline{Q_{S}}$ allows us to describe the relative decrease caused by the mobilized karst storage flow $\left(Q_{s}\right)$. The term $\lambda_{c} \cdot \overline{\Delta H_{2}}$ describes the relative contribution of the Jurassic aquifer on the west of the Matelles Fault. The term $\lambda_{d} \cdot \overline{\Delta H_{3}}$ allows us to describe the relative contribution from the matrix reservoir. In this model, the term $\lambda_{a} \cdot \overline{R_{e f f}}$ does not allow a description of the contribution from the effective rainfall; we fixed this parameter at $1 \%$ because we consider that most of the effective rainfall recharge information is already contained in the model's other components ( $\Delta H_{2}$ and $\Delta H_{3}$ ). This component enables one to describe the recharge phenomena associated with the fast flow that occurs during significant flooding $(Q>3000 \mathrm{l} / \mathrm{s})$. We assume that the component described refers to direct infiltration from losses associated with the temporary streams that form during floods.

\section{Results}

Rainfall data from three weather stations were used (Fig. 1): Saint-Martin de Londres (R1), Montpellier-Fréjorgues (R2), and Valflaunes (R3). The aim of the computation was to maximize the cross-correlation between $R_{\Sigma}$ and the overflow discharge ( $\left.Q r\right)$ at the Lez spring measured between 1987 and 2007. The linear combination obtained for $R_{\Sigma}$ is:

$$
R_{\Sigma}=0.34 * R 1+0.53 * R 2+0.13 * R 3
$$


The calibration of Module 1 was based on the natural high-water discharges (Qn = Qr+Qp for the period 1998-2006; Figure 5a); the natural low-water discharges are not known. The parameters of the transfer function (Eq. 6 ) shown on Figure 5 e are: $k 1=7.4$ days, $k 2=59$ days, $\theta=0.29$. The length of the impulse response is 324 days. The mean transit time $(\mathrm{Tm})$ associated with the normalized impulse response is the mean value of the lag (Pinault et al, 2005). The average transit time $(\mathrm{Tm})$ is 42 days. The first transfer model assumes that the regulation time (system memory) of the slow component of the karst system is less than a year (324 days; Figure 5e). This assumption is not restrictive because the karst system's spring begins to flow again with the first autumnal rains, and the low-water periods (recession) do not exceed a year. The model was validated with the natural high-water discharges for the 1987-1997 period (Figure 5b); it satisfactorily reproduces the high-water periods, and the Nash criterion of 0.67 (Nash and Stutcliff, 1970) is considered satisfactory, having been calculated on the high-water cycles for the 1987-2007 period. The area of the karst catchment basin providing recharge is estimated at $116 \mathrm{~km}^{2}$. The fast component (Qf) of the recharge flows only during significant floods ( $Q n>3000 \mathrm{l} / \mathrm{s}$ ) and contributes up to a maximum 7\% of the flood discharge.

For Module 2, the reference level is that measured at low water when the head becomes constant $\left(\mathrm{H}_{0}=60\right.$ m.a.s.l.) following groundwater-level disconnection from the Jurassic compartment lying east of the Matelles Fault. The groundwater level is described only by the slow component of the recharge, the fast component being unnecessary for the simulation. The impulse response for the slow component is shown in Figure $6 \mathrm{c}$. The average transit time $(\mathrm{Tm})$ of the normalized impulse response $\left(\tau_{2}\right)$ is 42 days. The regularization parameter $(w)$ is 0.1 . The length of the impulse response is 96 days. Module 2 enables a satisfactory reproduction of the daily changes of the groundwater level measured at the Suquet observation borehole (high Nash criterion $=0.88$ ). The model was validated with the water levels measured for the 2011-2012 period (Figure 6c): it satisfactorily reproduces the high-water and low-water periods, and the Nash criterion of 0.82 is considered 
satisfactory. The model nevertheless tends to overestimate the groundwater level after the first floods of the new hydrological cycle (autumn). The effective porosity $(\eta 2)$ is estimated at $0.37 \%$, which is a general value for the aquifer compartment drained by the Lirou overflow spring; the Suquet observation borehole taps the same drainage system just upstream of the intermittent spring. This second transfer model was used to simulate the groundwater level of the western compartment (1974-2010; Figure 9e) and the output of this module 2 modeling is one of the inputs to the fourth module of the Lez transfer model.

In Module 3, computing the effective porosity $(w s=\eta 3 / \operatorname{Max}[\Gamma])$ requires a knowledge of the base level $\left(H_{0}\right)$ corresponding to the piezometric level reached by the system in the absence of recharge and pumping (Pinault 2001, Pinault et al., 2005). Because in the present case the base level $\left(\mathrm{H}_{0}\right)$ cannot be deduced from the observed piezometric record, owing to the influence of pumping, it was characterized using the model using trial and error to obtain a maximum Nash criterion. The base level obtained is $\mathrm{H}_{0}=80$ m.a.s.l., which is an intermediate value in the observed variation range (61115 m.a.s.I.). The effective porosity $(\eta 3)$ is estimated at $0.91 \%$. The average transit times $(\mathrm{Tm})$ of the normalized impulse responses of the two contributions $\left(\Gamma_{3}\right.$ and $\left.\Gamma_{3 s}\right)$ are 47 days and 9 days respectively (Figure $7 b$ ). The regularization parameter $(w)$ is 0.1 . The length of the impulse response is 160 days. For offsets longer than 50 days, the non-parametric impulse response of effective rainfall shows oscillations which correspond to noise without physical meaning. Nevertheless, the length of the impulse response is significant because the tests conducted with a shorter length for the impulse response do not allow the modeling of the inertial response of the aquifer to effective rainfall. This third transfer model provides a satisfactory simulation of the daily evolution of the measured piezometry for the calibration period (Nash criterion $=0.82$, Figure 7a). The model was validated with the water levels measured for the 2008-2011 period (Figure 5d); it satisfactorily reproduces the highwater periods, and the Nash criterion of 0.69 is considered acceptable. The average recharge contribution is estimated at about $71.5 \%$, with the mobilized karst storage flow (Qs) explaining on 

average $28.5 \%$ of the measured piezometric variations. When the water level drops below the reference level $\left(\mathrm{H}_{0}=80 \mathrm{~m}\right)$, the piezometric variation appears to be controlled mainly by the mobilized storage flow (Qs) component, which can thus cause drawdown in the piezometer of nearly $13 \mathrm{~m}$. This third model was used to estimate the groundwater level within the karst for the period before 2003 and for that after 2005 . The record produced by this modeling forms one of the inputs to the fourth module of the Lez transfer model (1974-2008; Figure 9e).

The impulse responses $\left(\Gamma_{a}, \Gamma_{b}, \Gamma_{c}\right.$ and $\left.\Gamma_{d}\right)$ of Module 4 were computed for the shortest possible lags (4 days, Figure $8 \mathrm{c}$ ) to make the model stable, since the $\mathrm{H} 2(\mathrm{t})$ and $\mathrm{H} 3(\mathrm{t})$ variables are strongly correlated (Figure 10). The average transit times $(\mathrm{Tm})$ of the normalized impulse responses of the two contributions $\Gamma_{a}$ and $\Gamma_{b}$ are 2.5 days and 2 days respectively, but are less than 1 day (0.9 day) for contributions $\Gamma_{c}$ and $\Gamma_{d}$. The regularization parameter $(\mathrm{w})$ is 0.1 and the length of the impulse response is 4 days. The reference level $\mathrm{H}_{0}$, estimated by trial and error so that the model would be as close as possible to the observed groundwater level, is $\mathrm{H}_{0}=59.9$ m.a.s.l. Note that this reference level is similar to that obtained by the Suquet method $\left(\mathrm{H}_{0}=60 \mathrm{~m}\right)$ which reflects the moment when the karst west of the Matelles Fault is piezometrically disconnected from the rest of the aquifer located beneath the Cretaceous cover.

The model gives a very satisfactory reproduction of the daily changes of the measured groundwater level (calibration period from 29/04/2002 to 25/02/2004) with a Nash criterion of 0.97 (Figure 8a) and a very low standard deviation (0.02). The model has been used to simulate the groundwater level of the karst conduit for the periods before 2002 and after 2004 (Figure 9e). The model was validated with the water levels measured before 2002 (1974-2002 period) and after 2004 (20042011 period) (Figure 5a). This transfer model gives a satisfactory simulation of the daily changes of the water level measured in the conduit (Nash criterion $=0.68$ ). The periods of aquifer drawdown corresponding to the spring drying up are well reproduced. The simulated flood water levels are in some cases greater than the measured levels. 
Most of the groundwater level variation (44\%, Figure $9 \mathrm{~b})$ relative to the reference level $\left(H_{0}=59.9\right.$ m.a.s.I.) appears to be explained by the impulse response of the mobilized karst storage flow (Qs).

The average contribution of the matrix reservoir to the groundwater-level variation in the karst conduit is around $36 \%$. The remaining part (20\%) comes from the contribution of the karst lying west of the Matelles Fault. When the groundwater level in the conduit falls below 59.9 m.a.s.I. (reference level), the groundwater level variations appear to be mainly controlled by the mobilized karst storage flow (Qs), whose average contribution becomes greater than $90 \%$.

\section{Discussion}

\section{Sensitivity}

The time-invariant impulse response (IR) used to describe the dynamic response of a system to an instantaneous impulse can be objectively chosen as a mathematical function selected on physical grounds, or by the use of a non-parametric approach (Von Asmuth et al, 2002). In this study, the choice focused on the non-parametric approach because we believe that karst processes are not well explained by physical laws only. Indeed, the shape of the impulse response to an instantaneous impulse of recharge is the result of diffuse, fracture, and conduit flows with the potential existence of turbulent flows, themselves conditioned by vertical and horizontal heterogeneities. In order to assess the model's sensitivity to the choice of the non-parametric impulse response, rather than a parametric one, we also calibrated the transfer module of Suquet borehole with a parametric model. The convolution function used to perform the sensitivity test is a Gaussian-Exponential function (Eq. 5). Using this model, the recharge of a reservoir is described by the Gaussian function

$464\left[\exp \left(-\ln (2)\left(\frac{\left(t_{i}-T\right)}{D}\right)^{2}\right)\right]$ whereas the decreasing exponential function [exp $\left.\left(\frac{-t_{i} \ln (2)}{L}\right)\right]$ allows to represent the drainage from the reservoir; the succession of these two phenomena is the convolution product of the recharge law by the discharge law. The normalized impulse response of the parametric model is reported in Figure $6 c$, enabling a comparison with the impulse response of 
the non-parametric model. The non-parametric model produces a better fit than the parametric model both for the calibration period (Nash= 0.88 and 0.82 , respectively) and for the validation period (Nash $=0.82$ and 0.69 , respectively, Figures $6 \mathrm{~b}$ and $6 \mathrm{~d}$ ). The main difference concerns the peak response to the effective recharge, which occurs after a delay of two days. The response of the parametric model is smoothed compared to that determined by the non-parametric approach; the small oscillations present on the latter for offsets longer than 16 days correspond to low-level noise without physical meaning. This result demonstrates that karst phenomena are not always well explained by physical laws, i.e., the parametric function. The recession of the normalized impulse responses for the parametric and non-parametric functions (for lags $>16$ days) are very similar. This result shows that the optimization procedure used in the Tempo software to calculate the regularization parameter of the non-parametric function produces solutions that are smooth enough to be comparared to that obtained by a model of exponential decay. These results have reinforced our belief that the hydrogeological functioning of the Lez karst system would be better characterized by the use of a non-parametric impulse response.

As outlined by Long and Malher (2013), the modeling performance can be verified by using the length of the modeling's validation period. A lengthy validation period with a good fit allows us to evaluate the model's ability to predict the evolution of the system under other constraints (for example climate change and/or resource management scenarios). The modeling approach used in this study provides a very satisfactory reproduction of the daily time series of the groundwater level measured since 1974, with a Nash criterion of 0.68 and a low standard deviation (0.06). The time series calculated by the model are considered generally satisfactory, especially during periods of aquifer drawdown when the pumped discharge is greater than the natural discharge in the absence of pumping. In retrospect, these results validate the approach of reconstructing the natural flows of the Lez. Nevertheless, for some hydrological cycles, the model appears sensitive to summer rainfall episodes, when the calculated groundwater level may appear higher than the measured values. For 
the period prior to 1983 , the model tends to overestimate the drawdowns, which indicates that the natural discharges estimated by the modeling are probably underestimated. Indeed, we previously showed that the groundwater-level time series in the karst conduit are controlled solely by the impulse function of the mobilized storage flow (Figure $8 \mathrm{~b}$ ), as soon as the groundwater level falls below the $\mathrm{H}_{0}$ reference level of $59.9 \mathrm{~m}$ a.s.l. The under- and over-estimations of the simulated lowwater groundwater levels $(\mathrm{H}<65$ m.a.s.I.) are therefore related to the mobilized storage flow, and consequently to the natural flow estimated by modeling. An overestimation of the natural flows from the Lez spring results in an underestimation of the mobilized storage flow. The transfer model reflects this underestimation of Qs by simulating groundwater levels higher than the measured values (as with 1992, for example; Figure 9e). Conversely, an underestimation of the natural flow leads to a simulation of groundwater levels below the measured values (as with 2006, for example; Figure 9e).

In order to assess the model's sensitivity to the estimated natural discharge, the Lez groundwater level was simulated assuming that the spring discharge is known to within $\pm 10 \%$. The results of new groundwater-level simulations show that the model is generally not very sensitive to the uncertainty in the estimated Lez flow rates (figure not given). On the other hand, the results indicate that the modeling bias, highlighted in some hydrological cycles, is caused by poor estimation of the effective rainfall. The transfer model of Module 1 appears optimistic when significant rainfall events $(H>25$ $\mathrm{mm}$ ) occur during the summer low-water period. The simulated groundwater level during these periods therefore appears overestimated because the simulated natural flows are overestimated.

\section{Area of pumping influence}

The area of the karst catchment in which recharge occurs is estimated to be $116 \mathrm{~km}^{2}$, which corresponds to the area of outcropping Jurassic limestone in the hydrogeological basin $\left(100 \mathrm{~km}^{2}\right)$, to 
the contribution of occasional losses from temporary streams, and also to leakage from the overlying

518 Cretaceous. This area is comparable to the $120 \mathrm{~km}^{2}$ determined by Thiery and Bérard (1983) and the $130 \mathrm{~km}^{2}$ area parameterized by Fleury et al. (2008) in their reservoir model. The natural discharge of the Lez spring estimated by modeling is $1870 \mathrm{l} / \mathrm{s}(2 \sigma=590 \mathrm{l} / \mathrm{s}$, interannual average for the $1974-2010$ period). Also for this period, the average interannual discharge of the residual overflow rate (Qr) is $1030 \mathrm{l} / \mathrm{s}$, the pumping rate (Qp) is $995 \mathrm{l} / \mathrm{s}$, and the mobilized storage flow (Qs) is $150 \mathrm{l} / \mathrm{s}$.

The hydrogeological model developed in this study provides interesting information on the structure and flow regime of the Lez karst system. When the spring dries up $(\mathrm{H}<65$ m.a.s.I.), the time series of the water level in a karst conduit is controlled by the mobilized storage flow, which is a function of the pumping rate and the hydrogeological state of the karst in the absence of pumping (as described by the natural flow of Lez estimated by modeling). The amount of drawdown as a function of the volume pumped from the karst storage (Vs) is shown in Figure 11. It appears linearly related to the volume of water pumped from the karst storage, the slope of the line being estimated at $112,800 \mathrm{~m}^{3}$ per meter of drawdown. In the pumped section of the water column (between 35 and 65 m.a.s.l.). The results do not reveal any change in the hydrodynamic parameters with depth. For the water column below 35 m.a.s.l., a modification of the hydraulic parameters cannot be excluded. Only a pumping test in this section of the water column would provide the answer. The equivalent area of

534 karst storage mobilized by pumping has been estimated from the slope $\left(112,800 \mathrm{~m}^{3} / \mathrm{m} \pm 1800 \mathrm{~m}^{3} / \mathrm{m}\right)$ 535 and the effective porosity (0.91\%) calculated by Module 3, which characterizes the karst matrix below the Cretaceous cover. Assuming an elliptical groundwater level surface within the matrix tending toward the conduits, the area of pumping influence around the network of karst conduits is estimated at $59 \mathrm{~km}^{2}$, which is only a small fraction of the Lez spring's groundwater basin.

\section{Active management}

540 Hydrogeologically, reconstructing the Lez spring's natural flow makes it possible to characterize the

541 development of the aquifer's water resources since the onset of 'active management' based on 
drilling (1983). Analysis of the reconstructed natural flows for the 1974-2010 period shows that the volumes extracted annually are generally less than the annual recharge (Figure 11a). For the rainfalldeficient years $(1983,1998,2007)$, the pumped volumes are comparable to the volume of recharge $(V p \sim V s)$. The volumes of water pumped from the karst storage on average represent $18 \%$ (Vs/Vp ratio) of the mean annual pumped volumes ( 32.3 million $\mathrm{m}^{3}$; Figure $11 \mathrm{~b}$ ). The $\mathrm{Vs} / \mathrm{Vp}$ ratio rises to $30 \%$ in the rainfall-deficient years. Figure $11 \mathrm{~b}$ also clearly shows the moment at which the active management of the Lez resource was modified (1983).

The annual trend of the different volumes ( $V n, V p$, and $V s)$ and the $V s / V p$ ratio are shown in Figure 12 (interannual average over the period 1983-2010). The volumes of water pumped from the karst storage vary during the year (Figure $12 \mathrm{~b}$ ), with the $\mathrm{Vs} / \mathrm{Vp}$ ratio being highest in August and representing an interannual average of $55 \%$ of the pumped volume for this month. The interannual average $\mathrm{Vs} / \mathrm{Vn}$ ratio reaches $170 \%$ in August, indicating that the volume of water pumped from the karst storage is much higher than the average volume of water that would have flowed naturally in the absence of pumping (interannual average of $+70 \%$ ). The box plot (Figure $12 \mathrm{~d}$, e) illustrates the range in variability of the calculated ratios for the summer months (July, August, and September). For the rainfall-deficient years corresponding to the dry quinquennials (decile 0.8 ), the $\mathrm{Vs} / \mathrm{Vp}$ and $\mathrm{Vs} / \mathrm{Vn}$ ratios are respectively $70 \%$ and $235 \%$ in August.

\section{Conclusion}

The methodological approach developed in this study is based on breaking down the head variations of a karst system subjected to pumping, and on modeling the outlet discharges using transfer models. This approach has made it possible to model the groundwater level fluctuations in different compartments of the Lez karst aquifer, the residual flows at the spring, and the pumped karst storage flow. It is an overall semi-distributed approach enabling the aggregation of the hydrological responses of the various compartments interacting with each other. It constitutes a modeling 
alternative when (i) the complexity of the karst aquifer necessitates a more elaborate approach than

567 a simple lumped model, and (ii) the data necessary for a distributed model are not available. It has

568 also helped to reconstruct the natural flow of the spring in the absence of pumping. The uncertainty generated by this last aspect was the subject of a sensitivity analysis that showed the model to be relatively insensitive to the uncertainty in calculating the naturalized flow.

The models developed in this study reveal that the aquifer is not being overexploited. They will eventually allow the testing of various resource-management scenarios and assessments of the impacts on a) the time series of the karst system's total head (karst conduit and matrix), and b) the time series of residual flow. The data acquired will make it possible to evaluate the impacts of climate change and anthropogenic pressures on the short- and long-term water changes in the water resources, using wavelet analysis

\section{Acknowledgements}

578 This work was carried out under the Lez-GMU Project, in the framework of the BRGM's EAUR15 579 research program. The authors thank the Montpellier Agglomeration, the Water Agency Rhone580 Méditerranée-Corse, and the Hérault General Council, as well as the BRGM, for their funding 581 support.

582 The authors also wish to thank Barbara Malher and the anonymous referee for their helpful 583 comments, which led to substantial improvements in the manuscript. 


\section{Figure captions}

587

588

589

590

591

592

593

594

595

596

597

598

599

600

601

602

603

604

605

Figure 1: Simplified map of the lithotectonic units in the study area. Jurassic limestone outcrops correspond to the main recharge zones.

Figure 2: Interpretative geological cross section (NW - SE) of the Lez aquifer and architecture of the models used to simulate (1) the natural Lez spring discharge from effective rainfall; (2) the water level in the karst conduit (Suquet borehole) located close to the intermittent Lirou karst spring fed by effective rainfall; (3) water level in the matrix (Laudou piezometer) fed by effective rainfall and the storage flow (Qs) mobilized by pumping; and (4) water level in main conduit (Lez borehole) fed by effective rainfall, Jurassic contribution from aquifer located west of the Matelles Fault (2), matrix contribution (3), and contribution of the storage flow (Qs) mobilized by pumping.

Figure 3: Cross section of the karst network upstream of the Lez spring.

Figure 4: Changes in water levels in the karst conduit (Lez and Suquet boreholes, Claret piezometer) and matrix (Laudou piezometer) for the period 2000-2009.

Figure 5: Module 1 - Inverse modelling of the natural discharge of the Lez spring on a daily time step. The observed and modelled natural discharges for flood and high-water periods are plotted for both the calibrated period (a) and simulated period (b). The Nash coefficient is 0.67 for the high waters of the 1987-2007 period. The natural discharges for the low-water periods are calculated from the impulse response of the slow component (e). The impulse responses of the infiltration threshold $\Omega(t)$ to rainfall and air temperature are also plotted $(c, d)$, as are the slow and fast normalized impulse responses of the effective recharge $(e, f)$. 
Figure 6: Module 2 - Inverse modeling of the water level in the karst conduit located close to the intermittent Lirou spring (Suquet borehole) on a daily time step. (a) Infiltration threshold used in calculating the effective rainfall. (b) Comparison between the observed and modeled water levels from non-parametric model. (c) Slow normalized impulse response to effective rainfall (the fast impulse response not detected) for non-parametric and parametric models. (d) Water level simulated for the 2000-2012 period.

Figure 7: Module 3 - Inverse modeling of the matrix water level (Laudou piezometer) on a daily time step. (a) Comparison between the observed and modeled water levels. (b) Slow normalized impulse response to effective rainfall (fast impulse response not detected) and impulse response to the mobilized karst storage flow (Qs). (c) Hydrograph separation of the two water-level related components (Fig. 2) - piezometric variations are expressed relative to the reference level $\left(H_{0}=80\right.$ m.a.s.I.). (d) Water levels simulated for the 2000-2011 period.

Figure 8: Module 4 - Inverse modeling of the water level measured in the main karst conduit at Lez (Lez borehole) on a daily time step. (a) Comparison between the observed and modeled water levels for the calibrated period. (b) Hydrograph separation of the four water-level related components of the transfer model (Fig. 2$)$ - piezometric variations are expressed relative to the reference level $\left(H_{0}=\right.$ 59.9 m.a.s.I.). (c) Normalized impulse responses of the four components.

Figure 9: (a) Comparison between the observed and modeled water levels for the 1974-2010 period. (b) Effective rainfall calculated for the 1974-2010 period. (c) Natural spring discharge (Qn), pumping discharge (Qp), and pumped karst storage flow (Qs) for the 1974-2010 period. (d) Residual spring discharge (Qr). (e) Detail of the transfer model inputs of the water levels measured in the main karst conduit (water levels modeled by the transfer models 2 and 3 (Fig. 2)

Figure 10: Cross correlogram of piezometric data used to describe the hydrodynamics of the Lez karst system. 
630 Figure 11: Evolution of the average monthly drawdown in terms of the pumped karst storage 631 volume.

632 Figure 12: Evolution of the various annual volumes of water for the 1974-2010 period. The evolution 633 of the $\mathrm{Vs} / \mathrm{Vp}$ ratio is plotted at annual scale.

634 Figure 13: (a) Trends of the various volumes of water (average interannual monthly for the 19836352010 period). The trends of the Vs/Vp and Vs/Vn ratios calculated for the 1983-2010 period are 636 plotted at monthly scale (b, c). The box plots of the $\mathrm{Vs} / \mathrm{Vp}$ and $\mathrm{Vs} / \mathrm{Vn}$ ratios are given for the summer 637 months ( $d$ and $e$ ). 


\section{References}

641 Aquilina L., Ladouche B., Doerfliger N., 2005. Recharge processes in karstic systems investigated through the

642 correlation of chemical and isotopic composition of rain and spring waters. Appl.Geochem. 20(12):2189-206.

643 Aquilina L., Ladouche B., Doerfliger N., 2006. Water storage and transfer in the epikarst of karstic systems

644 during high flow periods. Journal of Hydrology 327(3-4):472-85.

645 Avias J., 1992. Contrôles Géologiques des systèmes aquifères karstiques (s.a.k) de type méditerranéen :

646 l'exemple du S.A.K de la source du Lez-France-(Karstic aquifers of Mediterranean type, geological controls : Lez

647 Spring (North-Montpellierant karsts, France) example. Hydrogeology of Selected Karst Regions, AlH, Volume

$648 \quad 13: 89-113$.

649 Avias J., 1995 - Gestion active de l'exsurgence karstique de la source du Lez (Hérault, France) 1957-1994.

650 Hydrogéologie 1:113-127.

651 Bakalowicz M., 2005. Karst groundwater; a challenge for new resources. Hydrogeol. J. 13(1):148-60.

652 Bérard P., 1983. Alimentation en eau de la Ville de Montpellier. Captage de la source du Lez, commune de St-

653 Clément (Hérault). Etude des relations entre la source et son réservoir aquifère. Rapport $\mathrm{n}^{\circ} 2$, Définition des 654 unités hydrogéologiques. BRGM Report 83 SGN 325 LRO, 27 p.

655 Birk S, Liedl R, Sauter M (2000) Characterization of gypsum aquifers using a coupled continuum-pipe flow 656 model. In: Stauffer F, Kinzelbach W, Kovar K, Hoehn E (eds) Calibration and reliability in groundwater modelling, 657 vol 265. IAHS Publication, Idyllwild, pp 16-21

Birk S., Liedl R., Sauter M., Teutsch G., 2003. Hydraulic boundary conditions as a controlling factor in karst 659 genesis: A numerical modeling study on artesian conduit development in gypsum. Water Resources Research 39, Art. No. 1004. 

Mediterranean Lago facies deciphered. Basin Research 17:487-462. naturel. Mémoire Master 2, Univ. Avignon 2, 151 p. difference norms. Water Resour Res. 29(8):2629-2635. Characterization. Ground Water 47(3):414-26. calibration. Journal of Hydrology 327, 564- 577, doi:10.1016/j.jhydrol.2005.11.058 61:31-44. systeme karstique de Terrieu (Perimetre experimental). Ann. Sc. Univ. Besancon 25:195-210. doi :10.1016/j.jhydrol.2008.11.037

Contributrions to Hydrogeology

Clauzon G., Suc J.P., Popescu S.M., Marunteanu M., Rubino J.L., Marinescu F., Melinte M.C., 2005. Influence of Mediterranean sea-level changes on the Dacic Basin (Eastern Paratethys) during the late Neogene: the

Conroux Y., 2007. Caractérisation du fonctionnement hydrodynamique de l'aquifère karstique du Lez à l'état

Cornaton F. and Perrochet P., 2002. Analyticial 1D dual-porosity equivalent solution to 3D discrete singlecontinuum models. Application to karstic spring hydrograph modelling. Journal of Hydrology, 262, 165-176

Denic-Jukic V., Jukic D., 2003. Composite transfer functions for karst aquifers. Journal of Hydrology 274:80-94.

Dietrich C.R., Chapman T.G., 1993. Unit graph estimation and stabilization using quadratic programming and

Dorfliger N., Fleury P., Ladouche B., 2009. Inverse Modeling Approach to Allogenic Karst System

Doherty J. and Skahill B.E., 2006. An advanced regularization methodology for use in watershed model

Dreiss S.J., 1983. Linear unit-response functions as indicators of recharge areas for large karst springs. J. Hydrol.

Drogue C., Grillot J.C., 1976. Structure geologique et premieres observations piezometriques a la limite du sous-

Fleury P., Ladouche B., Conroux Y., Jourde H., Dörfliger N., 2008. Modelling the hydrologic functions of a karst aquifer under active water management - the Lez spring. Journal of Hydrology 365:235-243. 
Guilbot A., 1975. Modélisation des écoulements d'un aquifer karstique (liaison plui debit). Applications aux bassins de Saugras et du Lez. Thesis, Université Montpellier II Sciences et Techniques du Languedoc, 110 p.

Jukić D., Denić-Jukić V., 2009. Groundwater balance estimation in karst by using a conceptual rainfall-runoff model. Journal of Hydrology 373(3-4):302-315.

Karam Y., 1989. Essai de modélisation des écoulements dans un aquifère karstique. Exemple de la source du Lez (Hérault, France). Thesis, Université Montpellier II Sciences et Techniques du Languedoc, 210 p.

Lacas J.L., 1976. Introduction à la méthodologie d'étude et d'utilisation des champs hydrothermiques des aquifères karstiques: d'après l'exemple du site de l'exsurgence de la source du Lez (Hérault, France). Université Montpellier II Sciences et Techniques du Languedoc, CERGA. 68 p.

Liedl R., Sauter M., Hückinghaus D., Clemens T., Teutsch G., 2003. Simulation of the development of karst aquifers using a coupled continuum pipe flow model. Water Resources Research 39, Art. No. 1057.

Long A. J. and Mahler B. J. (2013).Prediction, time variance, and classification of hydraulic response to recharge in two karst aquifers. Hydrol. Earth Syst. Sci., 17, 281-294,doi:10.5194/hess-17-281-2013

Mangin A., 1975 - Contribution à l'étude hydrodynamique des aquifères karstiques (Contribution to hydrodynamic study of karstic aquifers) Thèse de Docteur en Sciences, Université de Dijon ;Annales de Speléologie, 1974,29,3, pp283-332;1974,29,4, pp495-601;1975 , 30, 1, pp21-124.

Marechal J.C., Ladouche B., Doerfliger N., Lachassagne P., 2008. Interpretation of pumping tests in a mixed flow karst system, Water Resources Research 44(5): doi: 10.1029/2007WR006288

Martínez-Santos P., Andreu J.M., 2010. Lumped and distributed approaches to model natural recharge in semiarid karst aquifers. Journal of Hydrology 388(3-4):389-98. doi:10.1016/j.jhydrol.2010.05.018

Mazzili N. (2011). Sensibilité et incertitude de modélisation sur les bassins versants a forte composante karstique, phD thesis, Université Montpellier II, Sciences et Techniques du Languedoc, 210p 
Mazzilli N., Guinot V., \& Jourde H. Sensitivity analysis of conceptual model calibration to initialisation bias

(2011). Application to karst spring discharge models. Advances in Water Resources 42(8), 1-16. doi:10.1016/j.advwatres.2012.03.020.

Moussu F., Oudin L., Plagnes V, Mangin A.and Bendjoudi H., 2011. A multi-objective calibration framework for rainfall-discharge models applied to karst systems Journal of Hydrology 400 364-376. doi:10.1016/j.jhydrol.2011.01.047

712

Nash J.E., Sutcliffe J.V., 1970. River flow forecasting through conceptual models part I -A discussion of principles. Journal of Hydrology 10(3):282-290.

Padilla A. and Antonio Pulido-Bosch A., 2008.Simple procedure to simulate karstic aquifers. Hydrol. Process. 22, 1876-1884. doi: 10.1002/hyp.6772

Paloc H., 1979. Alimentation en eau de la ville de Montpellier. Captage de la source du Lez, commune de St. Clément (Hérault). Etude documentaire préalable à l'établissement des périmètres de protection. BRGM Note de synthèse 79SGN319LRO, 47p.

Paloc H., 1987. Première évaluation des capacités de production d'eau par pompage du siphon amont de la grotte dite "Du Grand Boulidou". Commune des Matelles (Hérault). BRGM Report 87SGN604LRO, 44p.

Pinault J.L., 2001. Manuel utilisateur de TEMPO, logiciel de traitement et de modélisation des séries temporelles en hydrogéologie et en hydrogéochimie. BRGM Report RP-51459-FR, 221 p.

Pinault J.L., Pauwels H., Cann C., 2001a. Inverse modeling of the hydrological and the hydrochemical behavior of hydrosystems; application to nitrate transport and denitrification. Water Resour.Res. 37(8):2179-90. 37(8):2191-204. 
Pinault J.L, Doerfliger N., Ladouche B., Bakalowicz M., 2004. Characterizing a coastal karst aquifer using an inverse modeling approach; the saline springs of Thau, southern France. Water Resour. Res. 40(8):17.

Pinault J.L, Amraoui N., Golaz C., 2005. Groundwater-induced flooding in macropore-dominated hydrological system in the context of climate changes. Water Resour. Res. 41(5): W05001, doi:10.1029/2004WR003169.

Pinault J.L, Schomburgk S, 2006. Inverse modeling for characterizing surface water/groundwater exchanges. Water Resour.Res. 42(8): W08414, doi:10.1029/2005WR004587.

Pinault J.L, Allier D, 2007. Regionalization of rainfall for broad-scale modeling; an inverse approach. Water Resour.Res. 43(9): W09422, doi:10.1029/2006WR005642,.

Sivapalan M., 2003. Prediction in ungauged basins: a grand challenge for theoretical hydrology. Hydrol. Process. 17:3163-3170. doi: 10.1002/hyp.5155

Teutsch G., Sauter M., 1998. Distributed parameter modeling approaches in karst-hydrological investigations. Bull. Hydrogéol. 16:99-109.

Thiery D., Berard P. \& Camus A., 1983. Captage de la source du Lez : étude des relations entre la source et son réservoir aquifère. $E d . B R G M, 83 S G N 167 L R O, 95$ pp.

Tikhonov A., Arsenine V., 1976. Méthodes de résolution de problèmes mal posés. MIR, Moscow.

Tikhonov A.N., Goncharsky A.V. (Eds.), 1987. III-Posed Problems in the Natural Sciences. MIR, Moscow.

Von Asmuth, J. R., Bierkens M. F. P. and Maas K., 2002. Transfer function-noise modeling in continuous time using predefined impulse response functions, Water Resour. Res., 38(12), 1287, doi: 10.1029/2001WR001136 


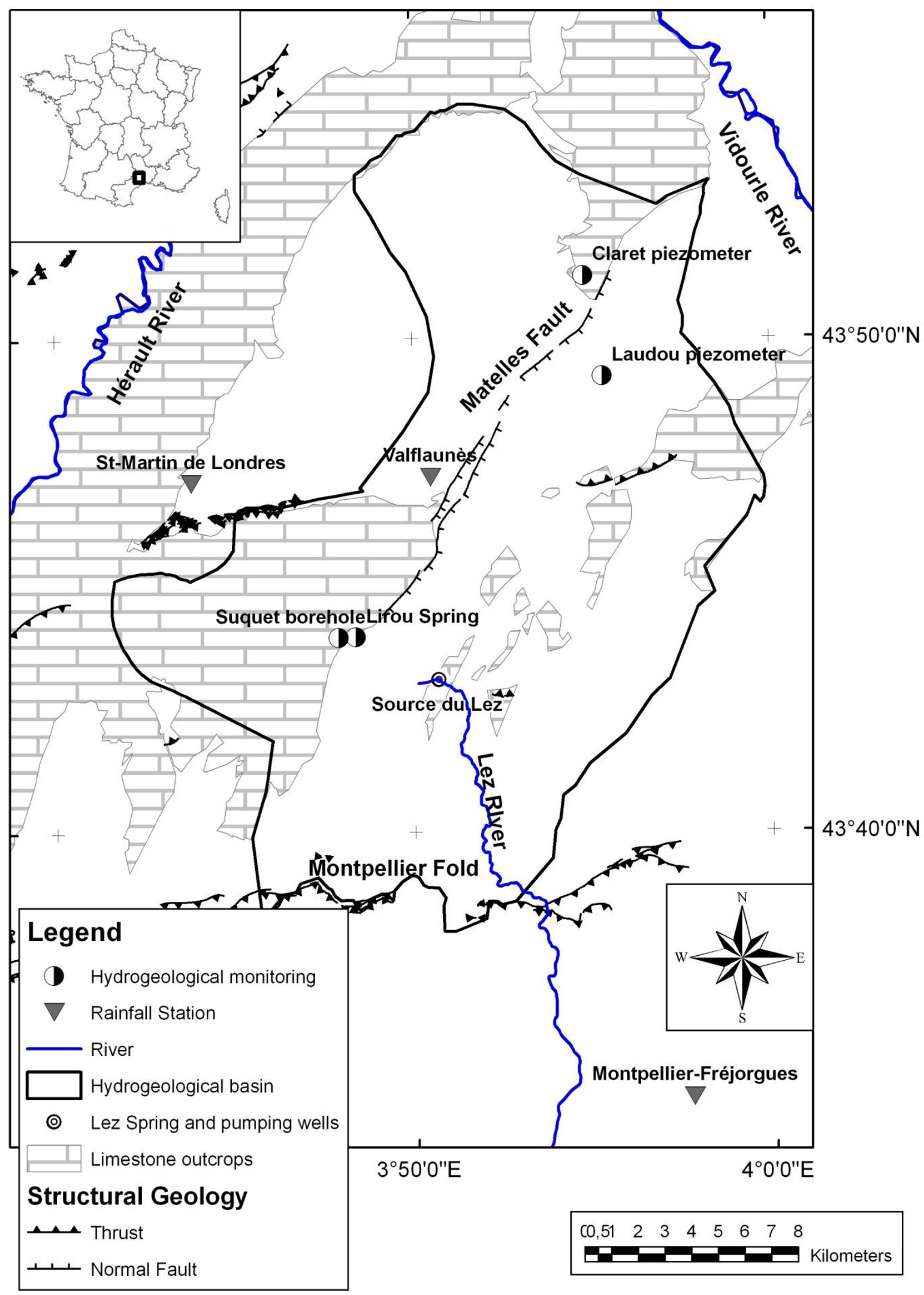

Figure 1. 
(a) NW

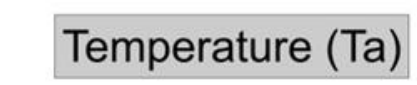

Rainfall (R)

SE
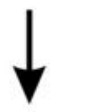

Suquet

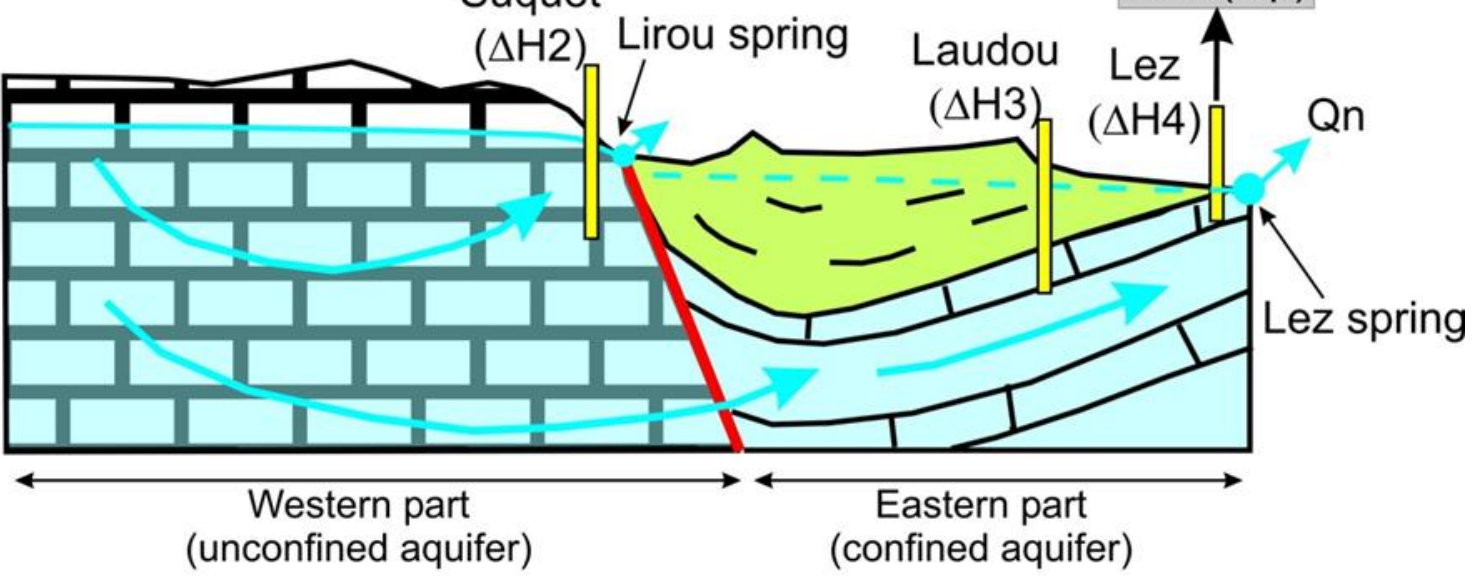

(b)
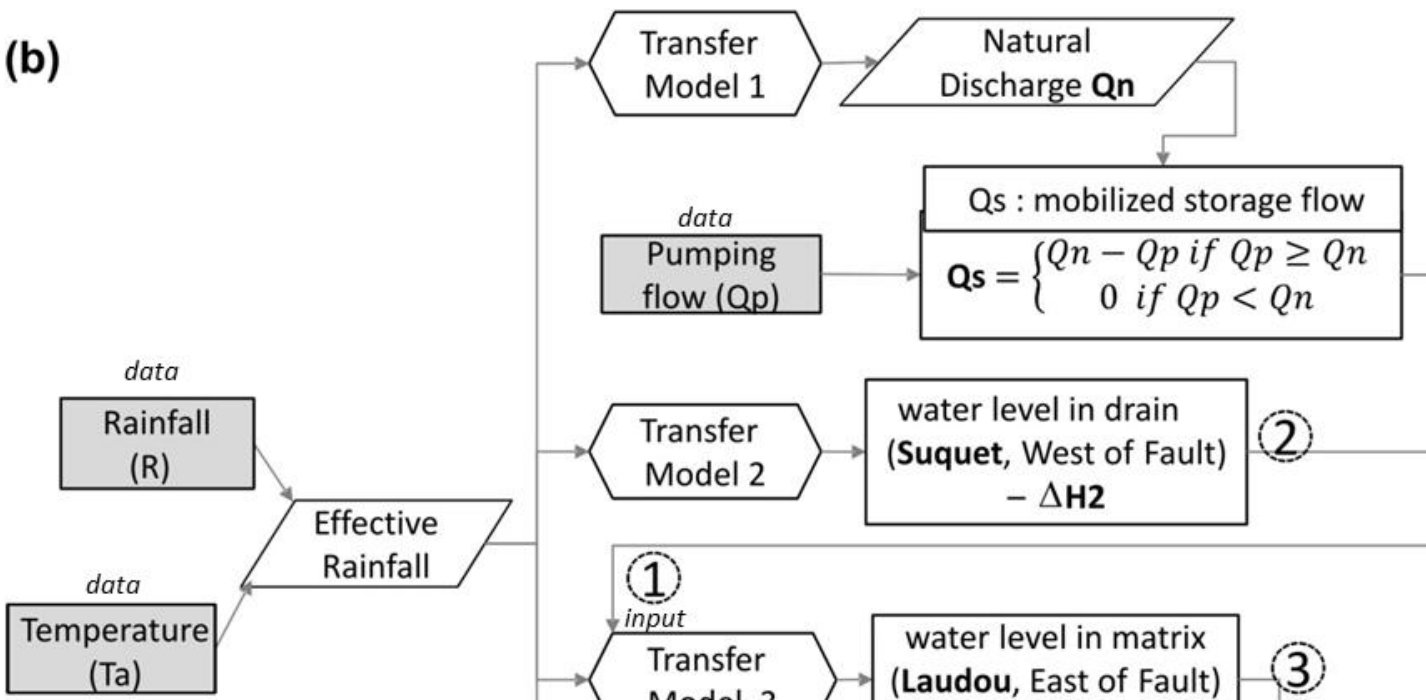

751

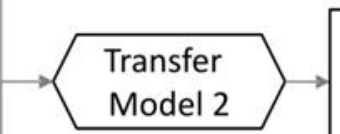

water level in drain

(Suquet, West of Fault)

$-\Delta \mathrm{H} 2$

(2)
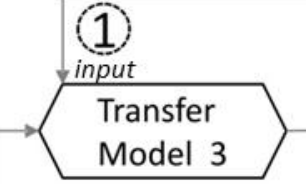

water level in matrix

(Laudou, East of Fault)

$-\triangle \mathrm{H} 3$

(3)

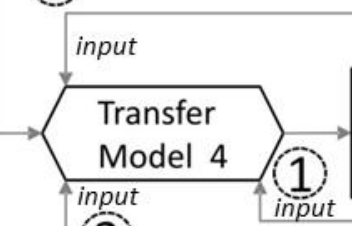

(2)

Figure 2 


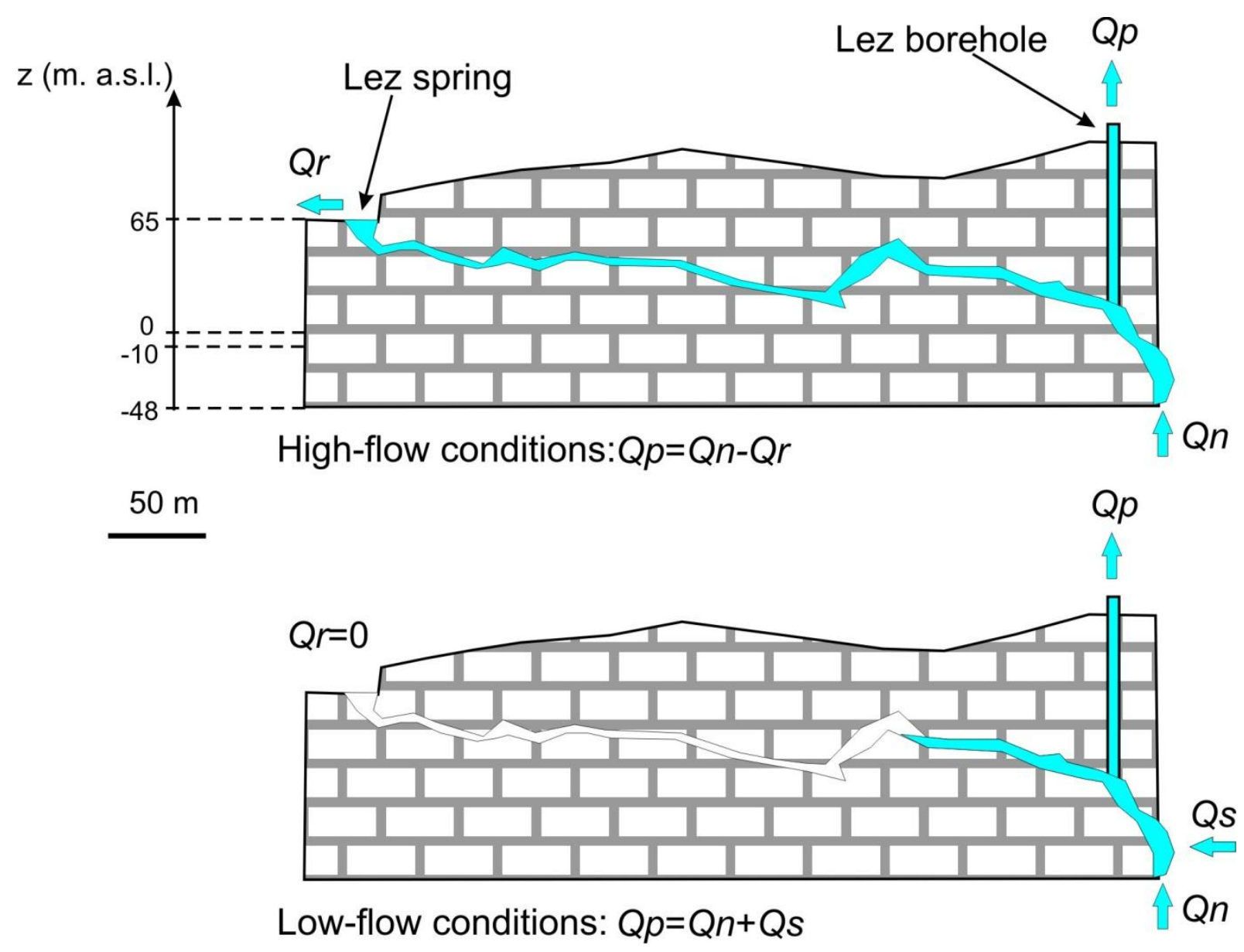

754

755 Figure 3 


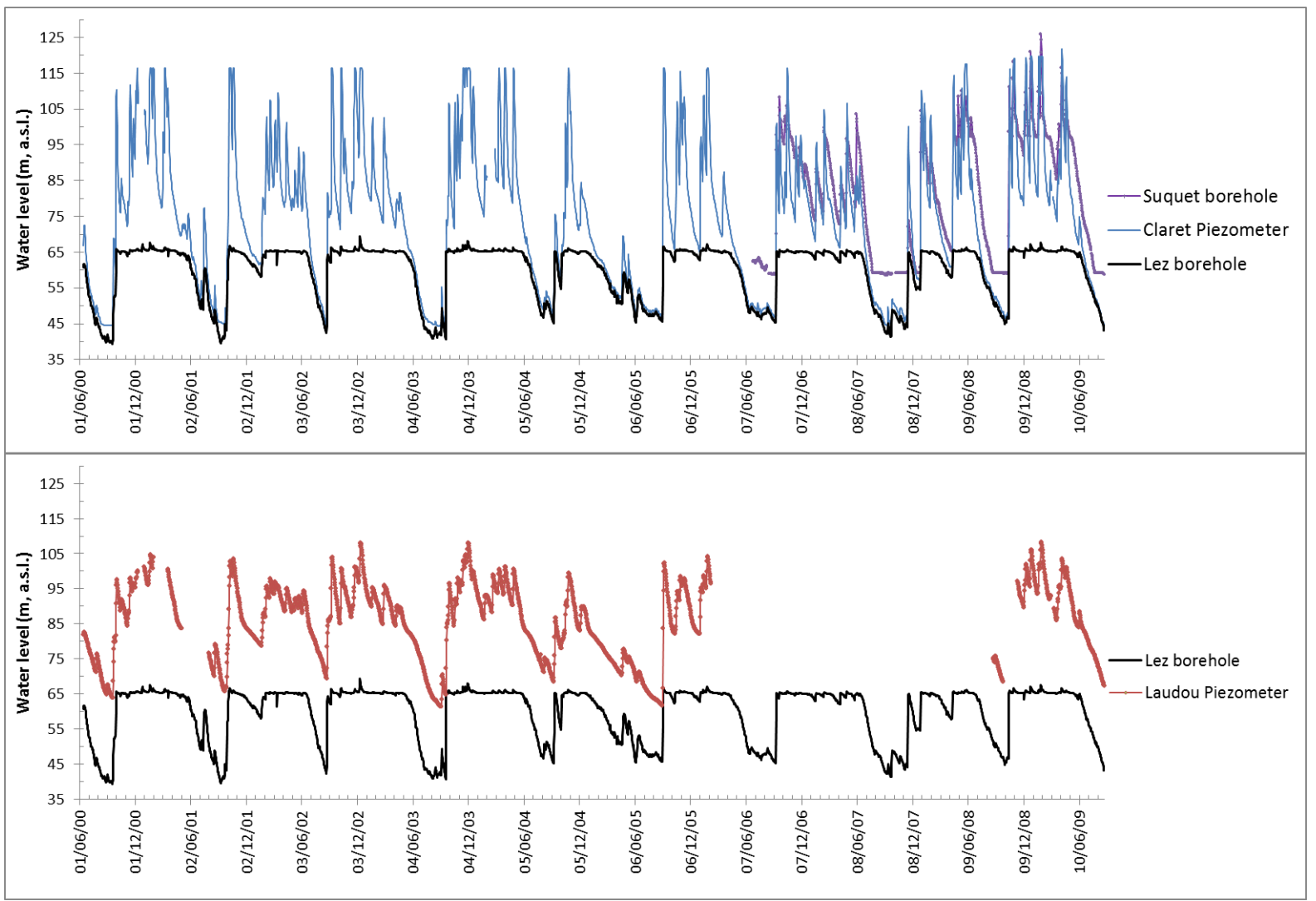

758

Figure 4

760 

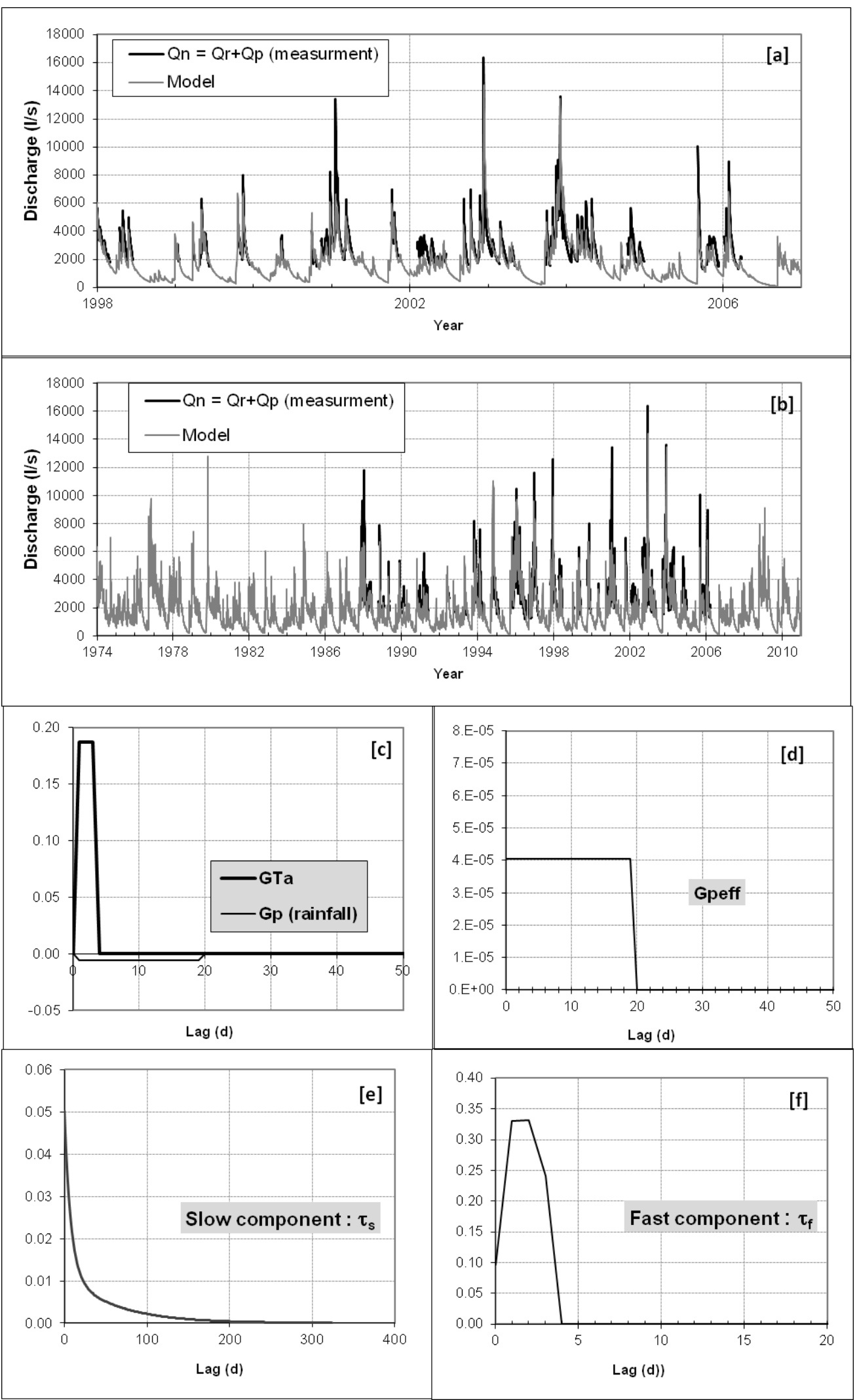

Figure 5 


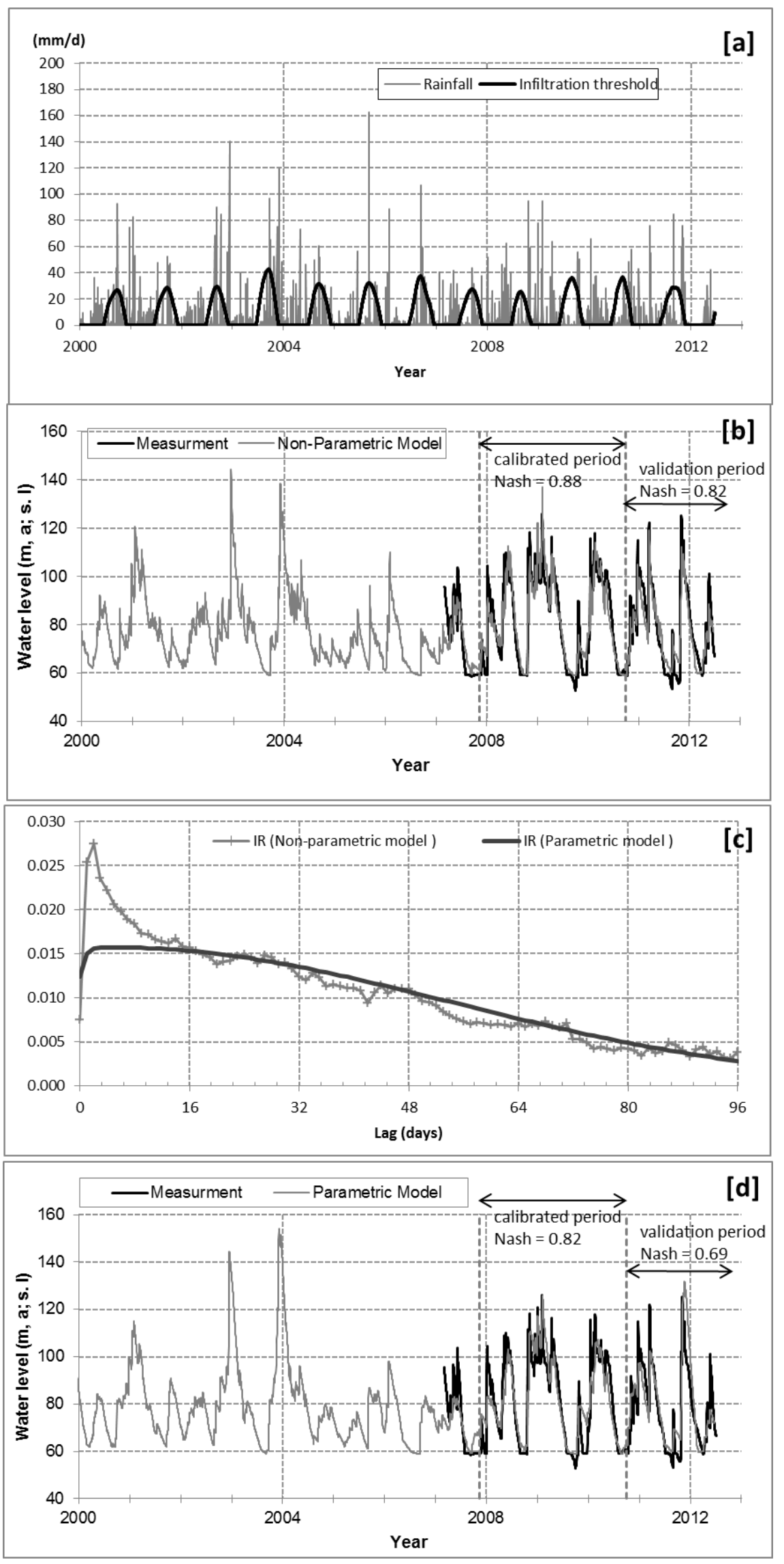

Figure 6 


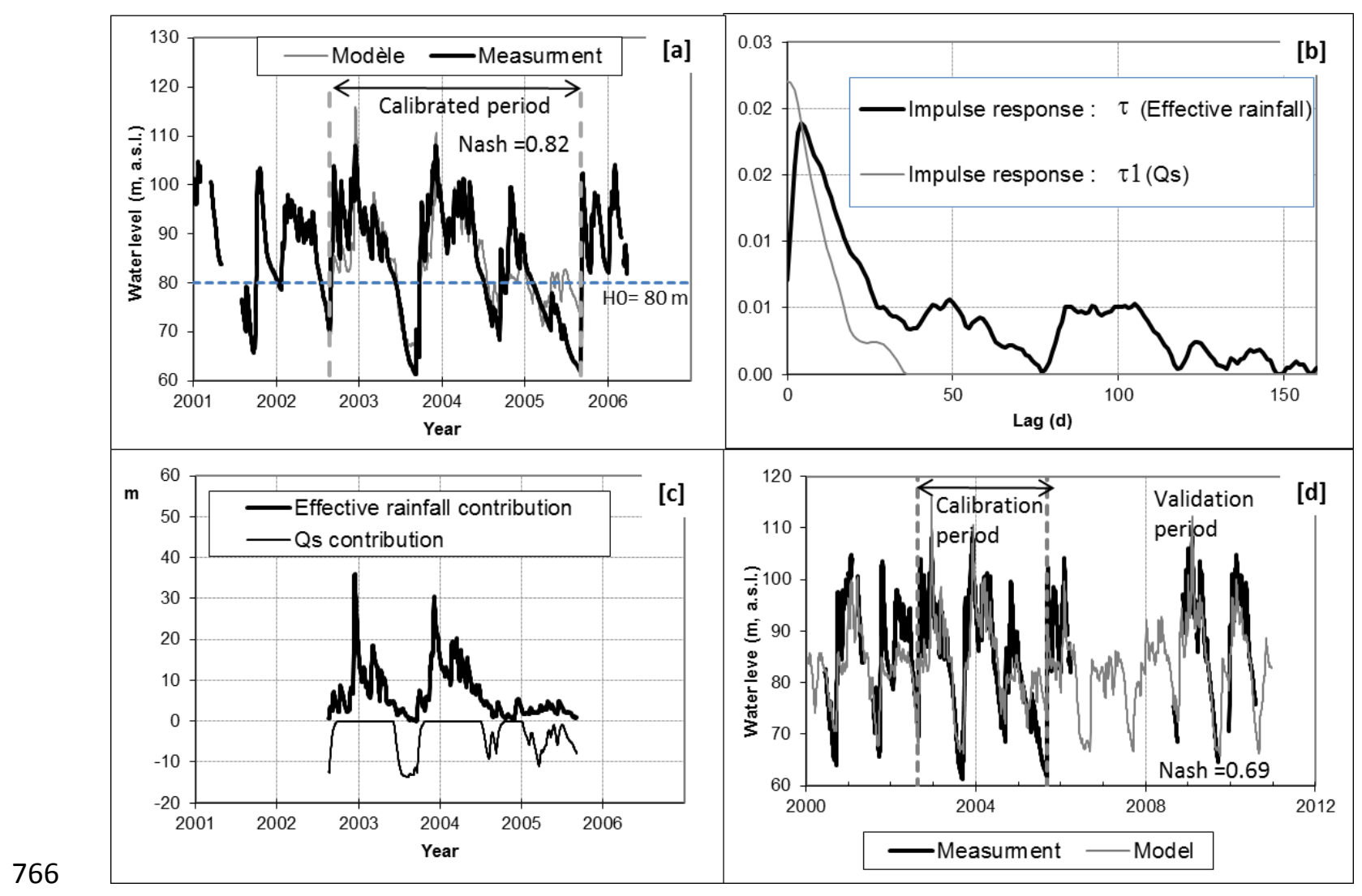

767 Figure 7 


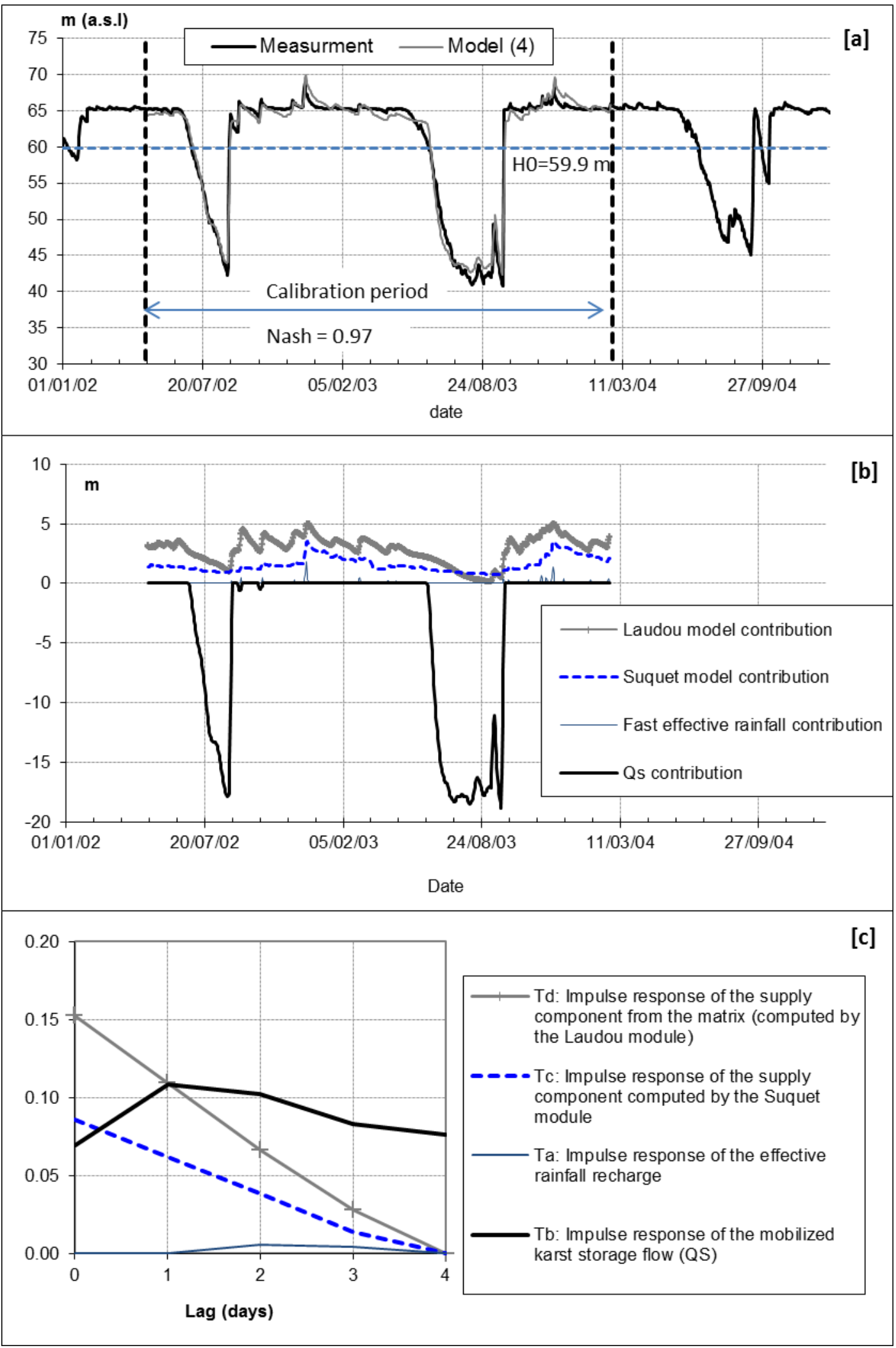

Figure 8 


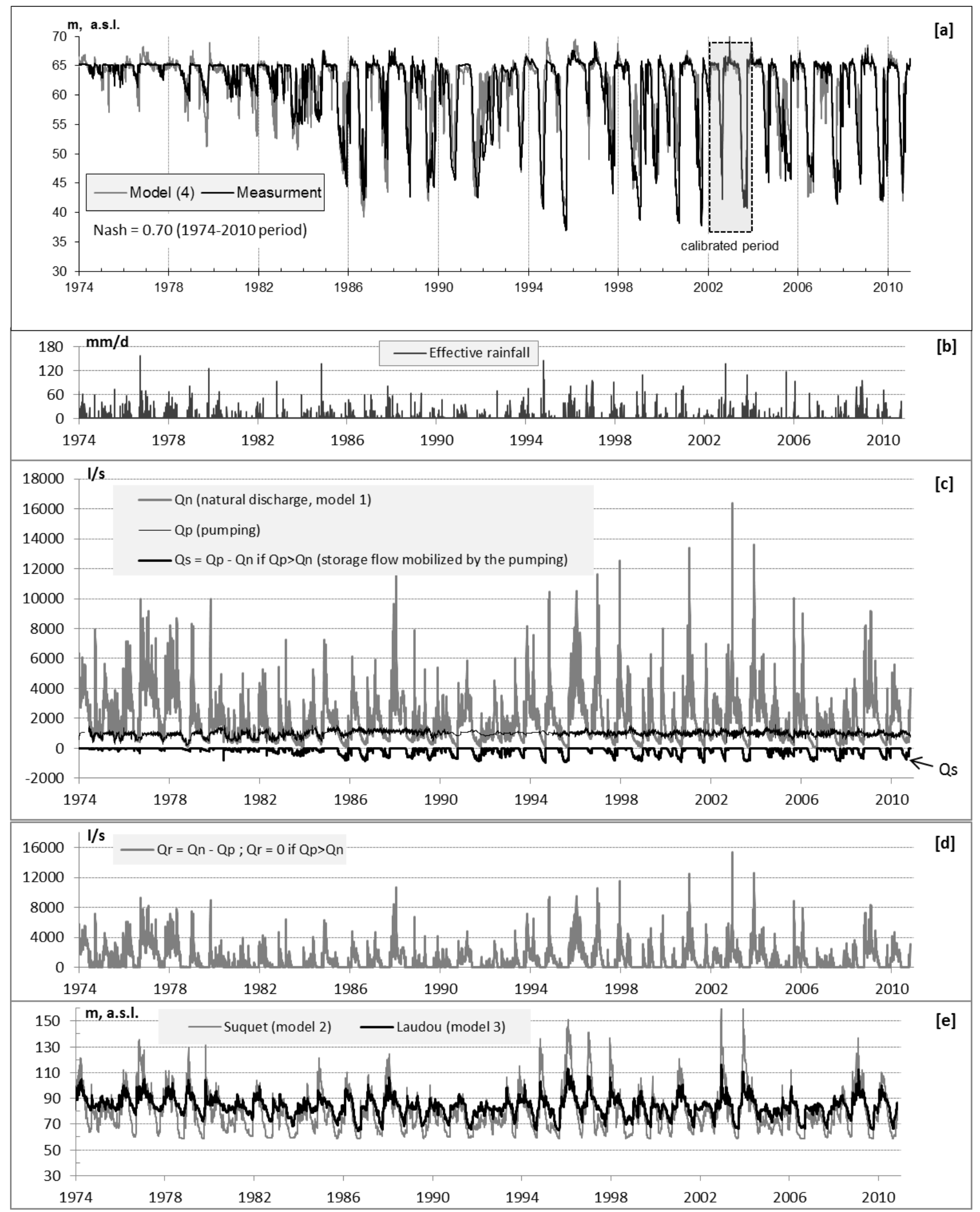

Figure 9. 


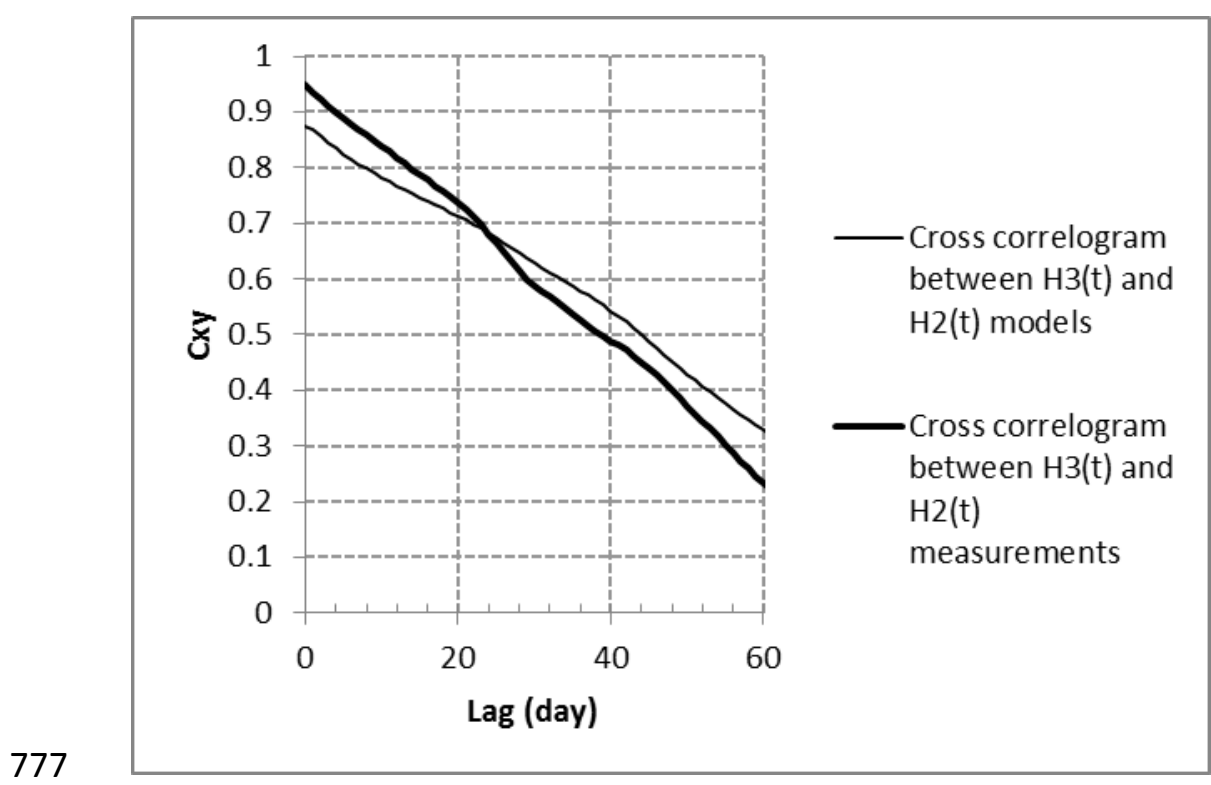

$778 \quad$ Figure 10 


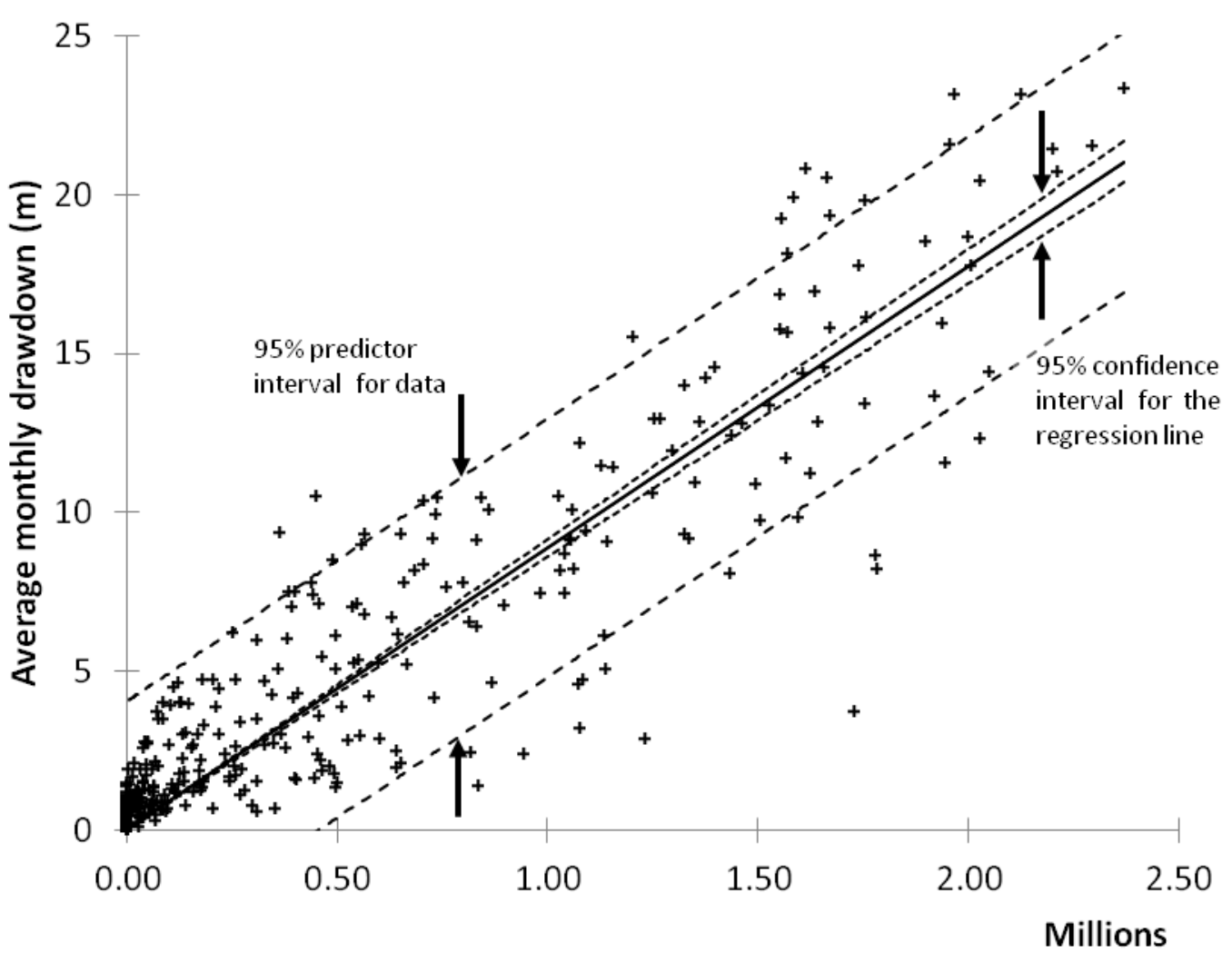

Vs (monthly, in m3)

Figure 11 


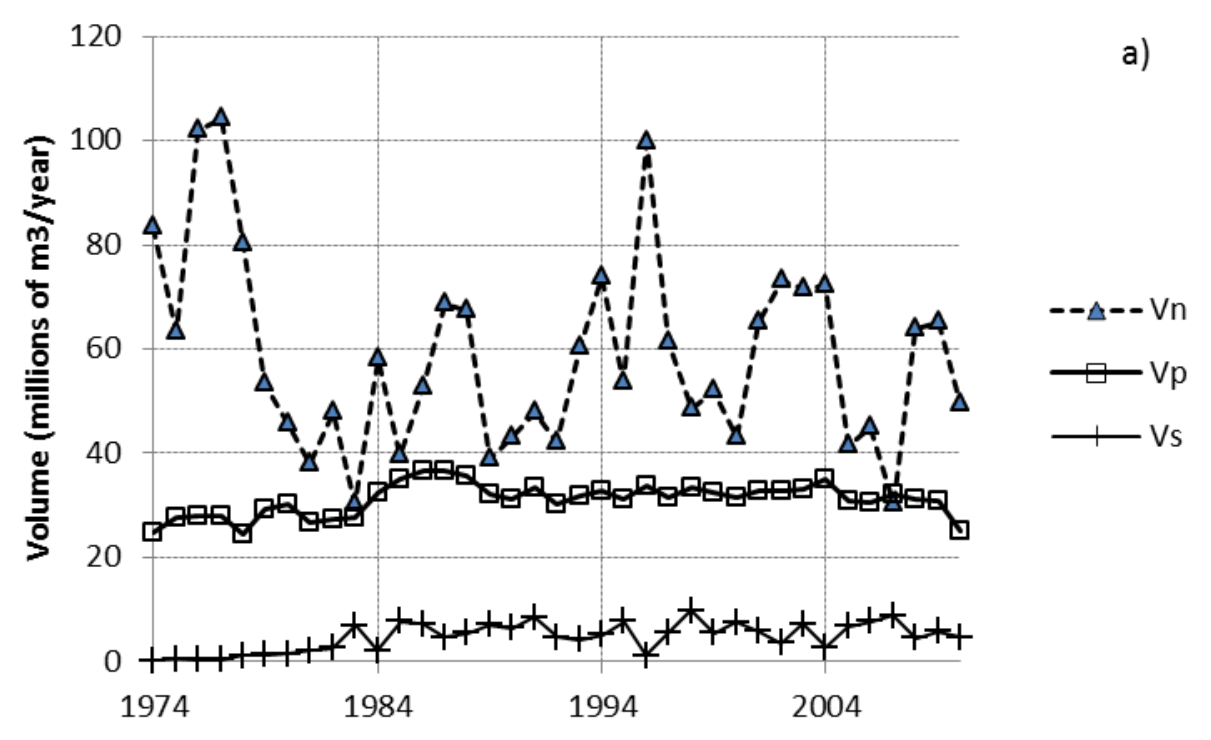

785

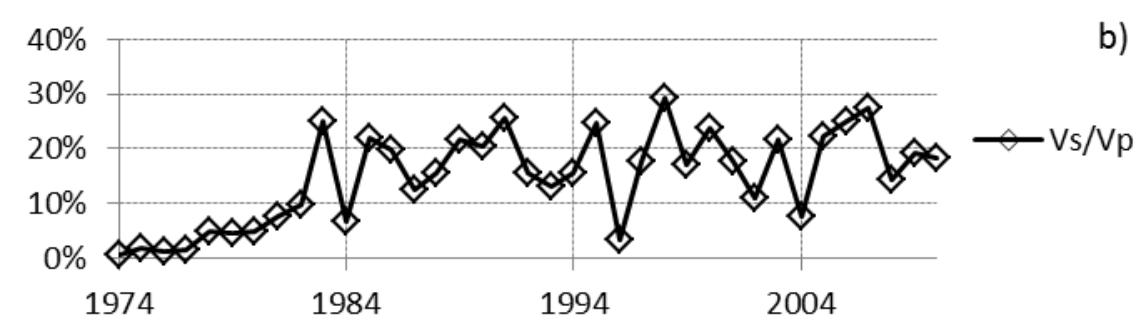

786 Figure 12

787 

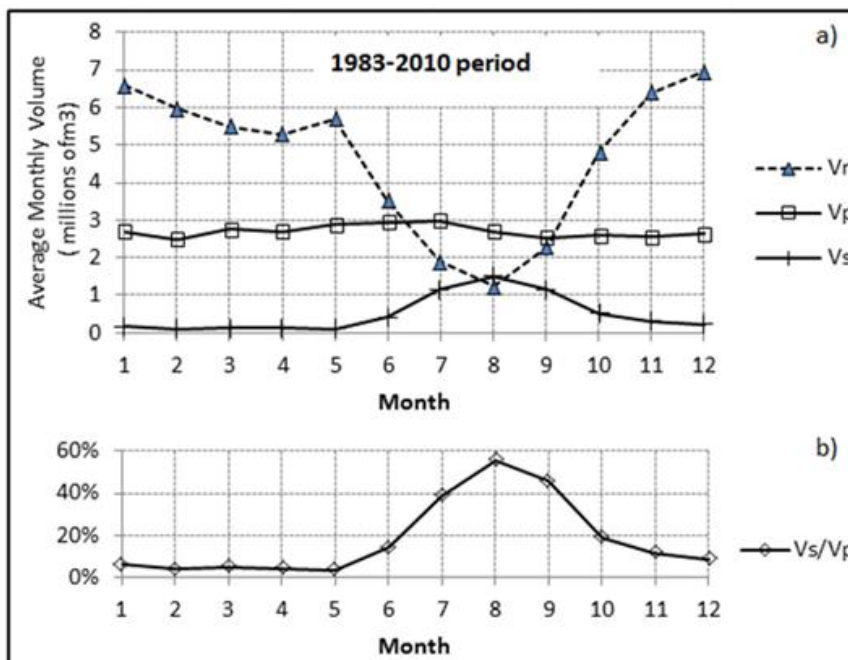

b)

d) Boxplot (Vs/Vp_July)

Boxplot

Boxplot

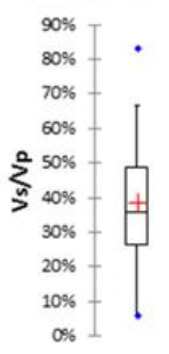

(Vs/Vp_August)

(Vs/Vp_Sept.)

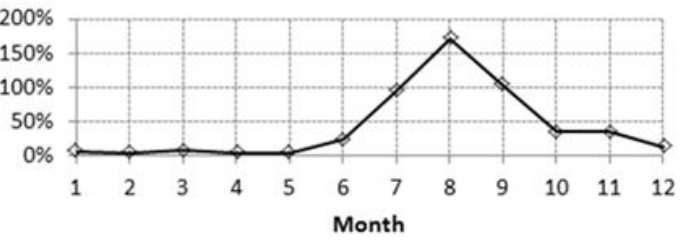

c)

e)

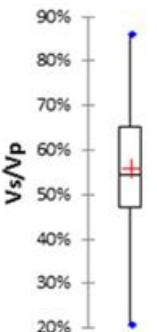

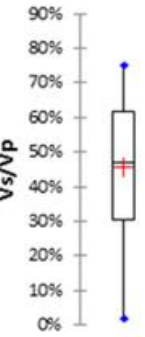

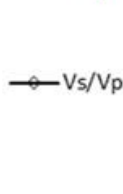

))

$20 \% 1$

September

60

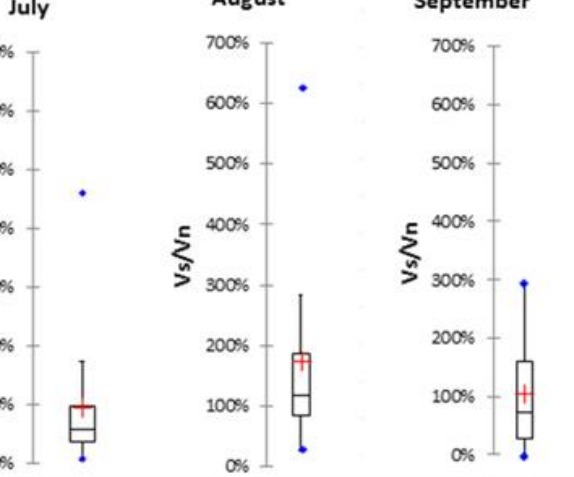

Figure 13.

791

792 